\title{
Maslow'un İhtiyaçlar Hiyerarşisinin Genç Bireylerin Yaşam Tarzları İle Girişimcilik Niyetleri Açısından İncelenmesi
}

\author{
İbrahim DURMUS ${ }^{1}$
}

$\ddot{O} z$

Günümüzde bireyler yaşam tarzları gereği çeşitli girişimsel faaliyetleri ihtiyaçları doğrultusunda gerçekleştirebilmektedirler. Özellikle genç bireyler teknolojik gelişmelere bağlı olarak sürekli değişen ekonomik ve sosyo-kültürel çevrede girişimcilik niyetleri farklılık gösterebilmektedir. Bu açıdan çalışma ile henüz eğitimi devam eden veya beş yıla kadar tamamlamış olan genç bireylerin yaşam tarzlarının girişimcilik niyetleri üzerindeki etkileri ve girişimcilik niyetlerinin de Maslow’un ihtiyaçlar hiyerarşisi üzerindeki etkileri ölçülmeye çalışılmıştır. Daha önce gerçekleştirilen çalışmalarda genellikle Maslow’un ihtiyaçlar hiyerarşisi kendi içerisindeki değiş̧kenler ile veya derecelendirme seviyelerine göre incelenmiştir. Ayrıca birçok araştırmada hiyerarşi bağımsız değişken olarak değerlendirilmiştir. Araştırmada daha önceki çalışmalardan farklı olarak hiyerarşik yapı derecelendirilerek değil bütün halinde ve bağımlı değişken olarak incelemeye alınmıştır. Yani uygulamada genç bireylerin yaşam tarzlarının girişimcilik niyeti üzerindeki etkisi ve girişimcilik niyetlerinin de ihtiyaçlar hiyerarşisi üzerindeki etkileri araștırılmıștır. Araştırma yöntemi oluşturulurken daha evvel gerçekleştirilen çalışmalardan faydalanılmış, elektronik anket yöntemi ile nicel veriler çerçevesinde yapısal eşitlik modellemesi uygulanmıştır. Çalışmada sadece bireylerin çeşitlilik aramaları değişkeninde anlamlı ilişki elde edilmemiş, diğer bütün değişkenler arasında anlamlı ilişkilere ulaşılmıştır. Uygulama sonuçlarında genç bireylerin kendine özgü olmalarının ve fikir liderliği yapmalarının girişimcilik niyetlerini pozitif olarak etkilediği görülmüştür. Çalışmada ayrıca genç bireylerin girişimcilik niyetlerinin fizyolojik ihtiyaçlarını, güvenlik ihtiyaçlarını, ait olma ihtiyaçlarını, saygı ihtiyaçlarını ve kendilerini gerçekleştirme ihtiyaçlarını pozitif olarak etkilediğ sonuçlarına ulaşılmıștır.

Anabtar Kelimeler: Yaşam tarzları, Girişimcilik niyeti, İhtiyaçlar hiyerarşisi

\section{Maslow's Hierarchy of Needs in terms of Lifestyle and Entrepreneurial Intentions of Young Individuals}

\section{Abstract}

Nowadays, individuals can perform various entrepreneurial activities in line with their needs due to their lifestyles. Entrepreneurship intentions may vary, especially in the economic and socio-cultural environment, which is constantly changing due to technological developments. In this respect, the effects of lifestyles on entrepreneurial intentions and the effects of entrepreneurial intentions on Maslow's needs hierarchy were studied. In previous studies, Maslow's hierarchy of needs was generally examined by variables within itself or by rating levels. In addition, in many studies, hierarchy has been evaluated as an independent variable. Unlike previous studies, the hierarchical structure was evaluated as a whole and as a dependent variable. In other words, the effect of lifestyle of young individuals on entrepreneurial intention and the effects of entrepreneurial intention on needs hierarchy were investigated. While creating the research method, previous studies were utilized and structural equation modeling was applied within the framework of quantitative data by electronic survey method. In the study, not only a significant relationship was found in the diversity searches of individuals, but significant relationships were reached between all other variables. In the results of the application, it is seen that the young individuals' being unique and leading the ideas positively affect their entrepreneurial intentions. In addition, it has been concluded that the entrepreneurship intention of young individuals positively affects their physiological needs, security needs, belonging needs, respect needs and self-realization needs.

Key Words: Lifestyles variables, Entrepreneurship intention, Hierarchy of needs

\section{Atıf İçin / Please Cite As:}

Durmuş, İ. (2020). Maslow’un ihtiyaçlar hiyerarşisinin genç bireylerin yaşam tarzları ile girişimcilik niyetleri açısından incelenmesi. Manas Sosyal Araștırmalar Dergisi, 9(3), 1731-1749.

Geliş Tarihi / Received Date: 14.05.2019

Kabul Tarihi / Accepted Date: 12.02.2020

\footnotetext{
1 Öğr. Gör. - Gümüșhane Üniversitesi, Sosyal Bilimler Meslek Yüksekokulu, ibrahimdurmus@gumushane.edu.tr 


\section{Giriş}

Günümüz dünyasında küresel ölçekte markaların, firmaların ve organizasyonların ülkelerin gelişmesinde oldukça etkili olmaları ülkemiz açısından genç girişimcilere oldukça fazla ihtiyaç duyulduğunu ortaya koymaktadır. Zira gençlerin erken yaşlarda özel sektörde ülke ekonomisine katkıda bulunmak için gerçekleştirebilecekleri girişimler küresel piyasaların hâkimiyet alanlanını sınırlayabilir. Yani girişimcilik faaliyetleri ne kadar fazla olur ise dişa bağımlı bir toplum (ekonomik olarak) olmak yerine ulusal kalkınmaya büyük destek (istihdam, yerli üretim, yerli markalar, yerel-bölgesel-ulusal kalkınma gibi) olabilecek faaliyetler gerçekleştirebilen bir toplum olunabilir. Bu durumda genç bireylerin aldıkları eğitim, aile içi paylaşılan değerler, yaşadığı yerin veya bölgenin sosyo-kültürel yapısı ve yaşadığı ülkenin ekonomik koşulları gibi değişkenler bireylerin yaşam tarzlarını, girişimcilik niyetlerini ve ihtiyaçlarını şekillendirebilecektir. Bu açıdan çalışmada bireylerin yaşam tarzlarını (kendine özgü olmak, çeşitlilik aramak, fikir liderliği yapmak) girişimcilik niyetlerini, girişimcilik niyetlerinin ise ihtiyaçlar hiyerarşisini (fizyolojik, güvenlik, ait olma, saygı ve kendini gerçekleştirme) ne oranda etkileyebileceği teorik bilgiler çerçevesinde ortaya koyulmaya çalışılmıştır.

İhtiyaç kavramı köken ve gelişim olarak büyük bir problem ile karşı karşıyadır. İş ile ilgili davranışları açıklamak için en sık kullanılan ihtiyaçların ifade edilmesi belirsizlik arz etmektedir. Maslow'un ihtiyaçlar hiyerarşisinin düzenlenebilmesi buna bağlı olabilmektedir (Salancik ve Pfeffer, 1977, s. 442). İhtiyaçlar hiyerarşisi teorisi, insan ihtiyaçlarının organiza bir sistem olarak işlemesini sağlar. Bu şekilde belirli bir birey için teori zamanın herhangi bir noktasında ihtiyaç memnuniyeti ve arzu arasındaki ilişkilerin kesin bir modelinin öngörür (Graham ve Balloun, 1973, s. 98). Bu açıdan Maslow'un ihtiyaçlar hiyerarşisi ile ilgili kavramlarda güvenilir ve geçerli ölçümler geliştirmek için daha fazla araştırmaya ihtiyaç vardır (Lester, 2013, s. 17). Bu eksikliğe bağlı olarak çalışma ile hem Maslow'un ihtiyaçlar hiyerarşisi değişkenlerine hem de literatüre farklı bakış açılarının kazandırılabilmesi amaçlanmaktadır.

Adam Smith girişimciyi tek bir birey olarak kabul ederken Mill ve Marshall bir veya daha fazla kişi tarafindan gerçekleştirilebilecek işlevler olarak ifade etmişlerdir (Massey, 1954, s. 249-250). Bu açıdan öğrencilerin veya yeni mezun olmuş genç girişimcilerin girişimcilik niyetlerinde; girişimcilik niyetlerini etkileyen faktörler başta olmak üzere onların girişimcilik önerileri, iş tercihleri, girişimcilik konusundaki eğitim anlayışları ve girişimcilik niyetlerini etkileyen diğer faktörler daha önce yapılan çalışmalar ş̧ı̆̆ında değerlendirmeye alınacaktır (Atef ve Al-Balushi, 2015, s. 74). Daha önce girişimcilik veya girişimcilik niyeti ile ilgili yapılan çalışmalar incelendiğinde girişimciliğin farklı türleri olduğu, girişimcilerin zorunlu olarak doğmadıkları ya da genetik olarak girişimciliğe yatkın olmadıkları ve bazı girişimcilik potansiyellerinin çoğunun bireylerde bulunduğu gözlemlenmiştir. Girişim niyetinde olan bireylerin girişimcilik faaliyetlerini gerçekleştirecekleri çevre genel olarak girişimcinin davranışını şekillendirmektedir (Kuratko, Morris ve Schindehutte, 2015, s. 7). Örneğin Dohse ve Walter (2012, s. 890) çalışmalarında öğrencilerin (genç girişimci) girişimcilik niyetlerinde yerleşim yerlerinin (çevre) etkili olduğunu ortaya koymuşlardır. Bu açıdan uygulamada genç girişimci adaylarının bulundukları çevrede; yaşam tarzları, girişimcilik niyetleri ve ihtiyaçlar hiyerarşisi ölçekleri araştırılmaya çalışılmıştır.

\section{Kavramsal Çerçeve}

\section{Yaşam Tarzları}

Psikolojik olarak bakıldığında her bir bireyin yaşam tecrübesi farklı olduğu için farklı davranış şekilleri, farklı düşünce yapısı ve farklı yaşam deneyimleri toplumsal düzen açısından değişiklik arz etmektedir (Maslow ve Honigmann, 1970, s. 321). O halde yaşam tarzları araştırmacılara bireyler arasındaki tutum farklılıklarının yorumlanmasına olanak sağlamaktadır (Yang, 2004, s. 207). Bu açıdan girişimcilik olgusu incelendiğinde farklı ortamlarda farklı türden işlerin gerçekleştirilmesi söz konusudur. Bunun için girişimciliği tek bir olgu ile ifade etmek pek doğru olmayacaktır. Çünkü her bir girişimci benzersiz bir yapıya sahiptir ve bu benzersiz girişimcilerin belli gruplar oluşturabilme çabaları söz konusu olmaktadır (Gartner, 2008, s. 359).

Toplumsal sınıflar ile ayrılmaz bir şekilde ilişkili olan farklı yaşam biçimleri deneysel bir temel ile tanımlanabilmektedir. İnsanların farklı yaşam tarzları veya alışkanlıkları olabilir. Ancak bireylerin genellikle ait olduğu sınıfın yaşam tarzlarına bağlı olduğunu kanıtlayan çalışmalar söz konusu olmaktadır (Tomlinson, 2003, s. 98). Bu açıldan çalışmada yaşam tarzları belirlenirken Yang'ın (2004, s. 203) tüketicilerin reklamlara yönelik tutumlarını ölçtüğü değiş̧kenler dikkate alınmıştır. Çalışmada öğrenci statüsünde (sınıf) olan veya mezun olmuş olan (beş yıla kadar) genç bireylerin yaşam tarzları; kendine özgü, çeşitlilik arayan ve fikir liderliği yapan bireyler olarak araştırılmaya çalışılmıştır. 


\section{Kendine Özgü Olmak}

Girişimcilikte bireyin isteğini gerçekleştirmesi amacı yer alıyor ise ekonomik ve çevresel etmenlerden ziyade kişisel faktörlerin incelenmesi gerekmektedir. Zira genç girişimcilerin kariyer hedeflerinde; tutumları, ilgi alanları, eğilimleri, niyetleri, görüşleri, risk ve kazanç algıları, motivasyonları, değerleri ve kişisel kapasiteleri gibi psikolojik süreçler dikkate alınmalıdır (Sahut ve Peris-Ortiz, 2014, s. 667).

Bireyler akrabalarına, arkadaşlarına ve meslektaşlarına göre rahat yaşamayı arzu edebilirler. $O$ halde girişimciler yeteneklerini de ortaya koyarak belirsizliği ve ekonomik durumu başarılı bir şekilde yönlendirip iyi yaşam sürmelerini sağlayabilirler (Montanye, 2006, s. 567). Bu açıdan kendine özgü hareket eden bireyler; istediklerini yapabilme kolaylığında olup plansız hareket edebilen ve sevdiği eylemleri yerine getirebilme konusunda rahat davranışlar sergileyebilen kişilerdir. Örnek olarak para kazanmanın tek amacının parayı harcamak olduğu düşüncesi verilebilir (Yang, 2004, s. 203).

Atef ve Al-Balushi (2015, s. 86) Umman gençliği üzerinde girişimcilik ile ilgili gerçekleştirdikleri çalışmalarında girişimciliğin öğrenilmesi gerektiğini, bireylerin girişimcilik için gerekli becerilere sahip olmalarının zorunluluk olduğu ve devlet sektöründe güvenli istihdamdan ziyade serbest meslek sahibi olmak için girişimciliğin eğitim sisteminin bir parçası olmasının gerekli olduğunu ifade etmişlerdir.

\section{Çeşitlilik Aramak}

Günümüzde bireylerin farklı yaşam tarzı deneyimleri söz konusu olmaktadır. Refah, yalnızlık, statü, sosyal ve ekonomik değişimler gibi zengin veya problemli bir yaşam tarzı değişkenleri çeşitliliği oluşturabilmektedir (Cloke, Milbourne ve Thomas, 1997, s. 227). Çeşitliliğe, eşitlik ve katılım perspektifinden bakıldığı zaman girişimcilik için katılım aracı olarak değerlendirilebilir (Pines, Lerner ve Schwartz, 2010, s. 192). O halde bireylerin girişimcilik niyetlerinde çeşitlilik aramaları onların eşit yaklaşım ile birlikte katılımı destekleyici yaklaşımlara sahip olmaları gerektiğini de ortaya koymaktadır.

Bireyler girişimcilik firsatlarını keşfedebilmeleri için belirli bir değişikliğin oluşturduğu yeni ilişkileri tanımlayabilmelidirler. Firsatı keşfetmede bireyler gerekli ön bilgiye sahip olsalar bile yeni yol gösterici ilişskileri göremez iseler bunu başaramayabilirler (Stam, 2008, s. 138). Bu açıdan Qian (2013, s. 2730) çalışmasında çeşitliliğin girişimcilik fırsatlarını ve girişimcilik fırsatlarındaki çeşitlilik algıllamasında önemli olduğunu ifade etmiştir. Ayrıca çeşitliliğin hem teknolojik açıdan hem de bölge ekonomisi açısından girişimcilik ile pozitif ve önemli bir ilişkisinin olduğunu ortaya koymuştur. Lazear (2005, s. 651) ise çalışmasında bireyin girişimci olma olasılığının kariyeri üzerinde sahip olduğu farklı rollerin sayısına ve eğitim hayatında edindikleri ile olumlu yönde ilişkili olduğunu ifade etmiştir. Ayrıca geçmişte riskli meslekleri seçme konusunda istekli olan bireylerin girişimci olma olasılıklarının daha yüksek olduğunu uygulamasında ortaya koymuştur.

\section{Fikir Liderliği Yapmak}

Bir sosyal sistemin üyeleri genellikle iş ilişkilerinde yabancılaşmış robotlar gibi davranmaktadırlar (Gemmill ve Oakley, 1992, s. 126). Bunun için bireyler iletissim kurma becerilerinde ne kadar fazla kişi ile diyalog gerçekleştirir iseler istenilen sonuçlara ulaşılmada o kadar başarılı olabilirler (Olson, 2002, s. 172). $\mathrm{O}$ halde günümüz genç girişimcileri hem normal hayatlarında hem de amaçlarına ulaşmak için fikir liderliği yaptıkları, yapacakları iş hayatlarında birçok birey ile sosyal ilişkilerin önemli olduğunu dikkate alarak faaliyetlerini buna göre yerine getirmeleri önemli olacaktır.

Gittikçe karmaşık bir hale gelen eğitim ortamlanında liderlik çalışmaları, değişen zorlukları ve yeni talepleri karşılayacak kadar esnek, farklı uzmanlık türleri ve esneklik biçimlerinin oluşmasını gerektirecektir (Harris ve Spillane, 2008, s. 31). O halde girişimcilik açısından değerlendirildiğinde firsat oluşturma, tanımlama ve fırsatları kullanmayı içeren davranışlar dikkate alınmalıdır. Ayrıca girişimcilikte büyüme ve yenilikçilik gibi dinamikleri barındıran görüşlere de yer verilmelidir (Audretsch, Kuratko ve Link, 2015, s. 709).

Gerçek girişimciler genellikle fikir sağlayıp problemleri ortaya çıkarmaktadırlar (Peters, Frehse ve Buhalis, 2008, s. 400). Kişisel bir nitelik olarak fikir liderliği yapmak kişisel özelliklerin özel bir kombinasyonunu ifade eder. Bu durum bireylerin nitelikleri ve yetenekleri ile ilgili bir olgudur (Bavelas, 1960 , s. 491). O halde fikir liderliği yapacak olan genç girişimcilerin yetenekleri ile henüz ortaya çıkarılmamış olan problemleri fark etmeleri ve problemlere çözümler üretebilmeleri, çevrelerindeki bireyleri de çözümler etrafında yönlendirebilme özelliklerine sahip olmaları gerekmektedir. 
Girişimcilikte servet elde etmenin yanı sıra iș olușturma fikri hesaba katılmaz ve girișimciliğin zevkli yönleri ile faydaları görülmez ise girişimcilik bir bütün olarak sistematik bir şekilde değerlendirilmiyor demektir (Welter, Baker, Audretsch ve Gartner, 2016, s. 5). Bu açıdan girişimcilik niyeti olan bireyler fikir liderliği yaparak yeni işlerinde girişimciliğin zevkli yönlerini ve faydalarını ortaya koyabilmelidirler. Ayrıca girişimciliğin bir bütün olarak incelenmesinde girişimcilik niyeti, yaşam tarzları ve ihtiyaçlar hiyerarşisi üçgeninin sistematik olarak değerlendirilmesi önemli sonuçlar ortaya koyabilir.

\section{Girişimcilik Niyeti}

Farklı teoriler ve girişimcilik üzerine bakış açıları dikkate alındığında bireylerin girişimcilik niyetleri üzerindeki etkileri kontrol etmek zor olacaktır (Crant, 1996, s. 44). Bu zorlukların yanında girişimciler; işlerini ve kişisel yaşamlarını dengelemek, topluma katkıda bulunmak, tutkularını devam ettirmek ve insanlara ahlaki davranmak istemektedirler (Claire, 2012, s. 31). O halde bireylerin girişimcilik niyetine etki edebilecek birçok faktörün varlı̆̆ını yaşam tarzları ve ihtiyaçlar hiyerarşisi ile açıklayabilmek bireylerin girişimcilik niyeti üzerine önemli katk1lar sağlayabilecektir.

Girişimcilikte yeni bir firma kurma süreci, bireyin bu davranışın arzu edilebilirliği ve sonucuna ilişkin beklentileri ile değer oluşturmasında beklenen bir süreçtir. Bireyler bu süreç üzerinde nadiren kontrol sahibi olurlar. Bir bireyin yeni bir firma kurabilmesi çoğu zaman bireyin algılanan yeterliliği, fon ve kaynak mevcudiyeti, fırsatın mevcudiyeti gibi dış faktörlere de bağlı olabilmektedir (Autıo, 2001, s. 146). O halde bu durum bazı ticari ve çevresel faktörlerin bireyleri ve firmaları girişimcilik davranışına yönlendirebileceğini ortaya koymaktadır (Brown, Davıdsson ve Wiklund, 2001, s. 955).

Ekonomiler, işletmeler, firmalar bölgesel ve ulusal refah arasındaki etkileşimin yanında girişimcilik araştırmaları; aktif vatandaşlık, eğitim sistemleri ve müfredat geliştirme gibi geniş kavramlar ile ifade edilmektedir (Kyrö ve Fayolle, 2008, s. 3). Bu durum yeni nesil bireysel düzeyde ulusal ve uluslararası iş ortamında girişimcilere olan ihtiyacın daha da belirgin hale geldiğini ortaya koymaktadır (Coviello, 2015, s. 24). O halde hem ulusal (yerel) hem de uluslararası ticarette girişimcilik öncü rol oynamaktadır (Zgheib ve Kowatly, 2011, s. 347).

Shinnar, Pruett ve Toney (2009, s. 154) öğrenciler üzerinde yaptıkları çalışmalarında çok az öğrencinin girişimcilik ve davranışsal niyetler açısından bir işe başlama konusunda kesin bir planı olduğu bazı öğrencilerin ise fikirlerinin ciddi olduğunu, işletme sahibi olmayı düşünen öğrencilerin çoğunun bunu belirsizce yaptıkları ve birkaçının ise hiç düşünmediğini çalışmalarında ortaya koymuşlardır. Ayrıca çalışmada davranışsal niyetler ile girişimcilik eğilimleri arasında önemli ilişki olduğu sonucuna ulaşmışlardır.

Olufunso (2010, s. 92-93) Afrika’da yapmış olduğu çalışmasında öğrencilerin girişimcilik niyetinin oldukça düşük olduğu sonuçlarına ulaşmıştır. Bu duruma sermayeye erişim imkânının fazla olmaması, yetkinlik eksikliği, devlet desteği, risk ve makroekonomik faktörlerin sebep olabileceğini vurgulamıştır. Yazar girişimcilik niyetinin önündeki engelleri azaltmanın girişimcilik eğitimi ile sağlanabileceğini ifade etmiştir. Ona göre girişimcilik eğitimdeki aksaklıkları önler ve bilgiyi geliştirmeye imkân sağlar. Yazar ayrıca girişimcilik yeteneklerinin; yaratıcılık, yenilikçilik, risk alma, başarılı girişimci rol modellerini yorumlayabilme ve firsatları belirleyebilme içeriklerinden oluştuğunu vurgulamıştır.

Franco, Haase ve Lautenschlager (2010, s. 269-270) uygulamalarında farklı Avrupa Bölgeleri'nde üniversite öğrencilerinin girişimcilik niyetlerini araştırmışlardır. Uygulamalarında öğrencilerin kendi işlerinde çalışmaya başlama kararı henüz almayanlar (potansiyel kurucu) ve gerçekçi niyetleri olan (kurucu) serbest meslek sahibi bireyler olarak ifade etmişlerdir. Çalışmada birçok öğrencinin girişimcilik niyetinin olduğunu, ailenin girişimcilik niyeti üzerinde doğrudan etkisinin olmadığ1 ve girişimcilik niyetleri açısından bölgesel farklılıkların (Batı-Doğu Alman yükseköğretim kurumlarında) olduğunu belirtmişlerdir.

Moi, Adeline ve Dyana (2011, s. 49) ise çalışmalarında genç yetişkin bireylerin girişimcilik niyetlerini etkileyen faktörleri incelemişlerdir. Çalışma sonuçlarında genç girişimcilerin girişimcilik niyetlerine; tutum, eğitim, akademik temel ve ailenin önemli etkilerinin olduğunu ortaya koymuşlardır. Ayrıca çalışmanın akademisyenler, eğitimciler ve politika yapıcılar için değerli etkilerinin olduğunu da ifade etmişlerdir.

Taatila ve Down (2012, s. 755) çalışmalarında öğrencilerin girişimcilere dönüştürülmesi hedefleniyor ise girişimcilik eğitiminde motivasyonun merkezi bir rol oynadı̆̆ını vurgulamışlardır. Ayrıca girişimcilik becerilerini geliştirmenin önemli olmasında girişimcilikten önce; problem çözme, yenilik ve daha genel gelişim becerilerinin ele alınabilmesinin gerektiğini ifade etmişlerdir. 


\section{Maslow'un İhtiyaçlar Hiyerarşisi}

Bir bireyin davranışının araştırılması davranış zincirini tamamlayan bir veya daha fazla hedeften itibaren birkaç eylem ile tanımlanabilir (Reiss, 2004, s. 179). Davranışçı teorileri modern bir ortam çerçevesinde değerlendirmek ilginç ve öğreticidir. Bu açıdan Maslow’un teorisi davranıșsal açıdan mükemmel bir kaynaktır (White ve Pierce, 2000, s. 697-698). Maslow ilk olarak 1954'te insanların işleri ile ilgili olarak motivasyon ve kişilik kavramları ile çeşitli kişisel ihtiyaçları nasıl karşıladıklarına dair teori ortaya koymuştur. Çalışmasında insanların genel olarak aynı sırayı takip ettikleri bir ihtiyaç tanıma ve memnuniyet modeli olduğunu ileri sürmüştür (Gawel, 1997, s. 1). Maslow'un teorisi felsefi, metodolojik ve hiyerarşik gerekçeler ile eleştirilmiştir. O insan ihtiyaçlarını daha düşük derecelerden daha yüksek seviyelere kadar çeşitlilik oluşturduğunu ifade etmiştir. Çalışmasında bir ihtiyaç yeterli bir şekilde yerine getirilince bireyin bir üst ihtiyaca geçeceğini vurgulamıştır ( Brenner, Carmack ve Weinstein, 1971, s. 359).

Maslow'un çalışmaları genel itibari ile manevi yönden fazla incelenmemiştir (Bouzenita ve Boulanouar, 2016, s. 68). Maslow ahlak sisteminin insan doğası hakkında bilinenlere bağlı olduğunu iddia etmiştir. Ahlaki felsefenin tam olarak anlaşılması için bireylerin psikolojik bakış açılarına odaklanmaları gerektiğini vurgulamıştır (Dennis ve Powers, 1974, s. 57). Bu açıdan Maslow'un teorisini araştıranlar genellikle nitel yaklaşımları tercih etmektedirler. İnsanların arzularını, ihtiyaçlarını analiz etmek ve Maslow'un görüşlerini değerlendirmek için karma bir yöntem de kullanılabilir (Saeednia, 2011, s. 3089). Bu açıdan uygulamada daha önce gerçekleştirilen nitel, nicel ve karma yöntemli çalışmaların bütününden yararlanılarak sonuçlar nicel veriler ışığında değerlendirmeye koyulabilecektir.

Maslow zor problemler karşısında kişisel gelişimin evrensel bir yol haritasını vererek ileri düzeyde bir ihtiyaçlar hiyerarşisi oluşturmuştur. O bir önceki ihtiyacın bir problemi farketme ile çözülebileceğini ifade etmiştir (Ventegodt, Merrick ve Andersen, 2003, s. 1051). Sürekli genişleyen ihtiyaç sisteminde; Maslow'un ihtiyaçlar teorisini tam olarak anlayabilmek için ihtiyaç sisteminin bazı temel özelliklerini dikkate almak gerekmektedir. Bu açıdan çalışma ihtiyaçlar hiyerarşisinin yanında (Chung, 1969, s. 224) yaşam tarzları ve girişimcilik niyeti ile literatüre dinamik ve kapsamlı katkılar sağlaması amaçlanmaktadır.

Memnuniyet eksikliği ilerlemenin önünde bir engeldir (Adler, 1977, s. 445). Taormina ve Gao (2013, s. 173) çalışmalarında Maslow'un beş temel ihtiyacın tamamının tatmin edilmesinin bireylerin yaşam memnuniyeti ile pozitif ve anlamlı şekilde ilişkili olduğu sonucuna ulaşmışlardır.

Temel ihtiyaçlar diyebileceğimiz en az beş temel ihtiyaç grubu vardır (Maslow, 1943, s. 392). Psikologlar ihtiyaçların belli bir önceliğe sahip olduğunu ifade ederler. Temel ihtiyaçlar karşılandıkça birey daha üst ihtiyaçlar arar. Temel ihtiyaçlar karşılanmadığı durumda daha yüksek ihtiyaçları karşılama çabaları ertelenmektedir. Bu açıdan Maslow beş temel ihtiyacı aşağıdaki gibi sıralamışlardır (Dye, Mills ve Weatherbee, 2005, s. 1377).

\section{Fizyolojik İhtiyaçlar}

Bireylerin hayatta kalmak için yeni gereksinimleri anlamında acil ihtiyaçları vardır (Smith, 1991, s. 423). Yani insanlar hayatta kalabilmeleri için yiyecek, su ve hava dahil olmak üzere temel ihtiyaçlara gereksinim duyarlar (Milheim, 2012, s. 161). Maslow her bir ihtiyaç türünün (veya seviyesinin) kavramsal olarak ilişkili oldukları çeşitli durumları birlikte açıklamanın ötesine geçmiştir. Mesela hayatta kalmak için gerekli olan su eksikliği, organizmayı su aramaya iten su ihtiyacını oluşturan şeydir. Başka bir örnek vermek gerekirse; iş, bir ihtiyaç olarak değil onun olmayışı asıl ihtiyacı tanımlayan şey olarak ifade edilebilir (Taormina ve Gao, 2013, s. 156). O halde girişimcilik niyeti açısından bakıldığında girişim bir ihtiyaç olarak değil onun meydana getirilmemesi (işsiz kalmak gibi) asıl ihtiyacı tanımlayan şey olarak ifade edilebilir.

Belirli bir ihtiyaçtan duyulan memnuniyet ne kadar yüksek ise ihtiyacın önemi o kadar düşük ve bir sonraki ihtiyaç düzeyinin önemi o kadar yüksek olur (Berl, Williamson ve Powell, 1984, s. 34). Taormina ve Gao (2013, s. 173) uygulamalarında fizyolojik ve saygı ihtiyacının karşılanmasının önemli olduğunu ifade etmişlerdir. Ayrıca fizyolojik ihtiyacın diğer dört ihtiyaç seviyesi için belirleyici bir rolü olsa da çalışmalarında kendini gerçekleştirme ile yüksek bir korelasyona sahip olduğu sonucuna ulaşmışlardır.

\section{Güvenlik İhtiyaçları}

Fizyolojik ihtiyaçlar nispi olarak iyi bir şekilde bölümlenmiş ise yeni bir ihtiyaç olarak değerlendirebilecek güvenlik ihtiyacı meydana gelir (Maslow, 1943, s. 375). Güvenlik ihtiyacı psikolojik ve fiziksel tehditleri en aza indiren, iyi olma hissini teşvik eden istikrarlı, düzenli ve kontrollü bir ortam gereksinimine odaklanır (Smith, Gregory ve Pugh, 1981, s. 561). Yani insanların emniyete veya güvenliğe 
ihtiyaçları vardır. Güvenlik ihtiyacı hayatta kalmak için önemlidir fakat fizyolojik ihtiyaçlar kadar zorunlu değildir. Güvenlik ihtiyaçları; istihdam, sağlık, güvenli yerleşim yeri ve çevre unsurlarından oluşmaktadır (Zakaria ve Malek, 2014, s. 43).

Güvenlik ihtiyacı karşılanmadı̆̆ında korku, endişe ve kaygılara sebep olabilir. Maslow hiyerarşisinde korkuların giderilip, yaşam kalitesinin iyileştirilmesi ile piramidin bir üst seviyesine çıkılabileceğini ifade etmiştir (Zalenski ve Raspa, 2006, s. 1123). Podesch1 ve Podesch1 (1973-74, s. 61) çalışmalarında egemen (baskın) olan bireylerin kendine güven duygusu yaşadıklarını ifade etmişlerdir. Ayrıca bu tarz bireylerin kendine güvenen, yüksek öz değerlere sahip ve genel itibari ile yetenek veya üstünlük duygularına sahip olduklarını belirtmişlerdir. Ayrıca alt kademe bireylerde ise utangaçlık, çekingenlik, korku ve öz bilinç gibi duyguların olduğunu ortaya koymuşlardır. Uygulamalarında Maslow'da en önemli olanın insanda güven ve özgüvenin bir arada olduğu durumlarda egemenlik (baskın) / itaat'in önemsizleştiğini çalışma sonuçları ile ifade etmişlerdir.

\section{Ait Olma İhtiyaçları}

Temel güvenlik koşulları yerine getirildikten sonra ait olma ihtiyacı ortaya çıkar. Bu alan aidiyet, dostluk ve sevgiye olan ihtiyacı içerir (Benson ve Dundıs, 2003, s. 316). Ait olma ihtiyacı; arkadaşlıklar, romantik ilişkiler ve aile gibi unsurların yanında sosyal ve dini grupların desteği ile de gerçekleşebilmektedir. Maslow bu ihtiyacın fizyolojik ve güvenlik ihtiyacından daha az temel oluşturduğunu ifade etmiştir (Zakaria ve Malek, 2014, s. 43-44).

Bireylerde daha düşük ihtiyaçların (fizyolojik, güvenlik ve ait olma) karşılanması onların daha yüksek ihtiyaçlar1 (sayg1 ve kendini gerçekleştirme) aramalarına sebep olabilmektedir (Gratton, 1980, s. 464). Taormina ve Gao (2013, s. 172) çalışmalarında aileden verilen duygusal desteğin ait olma ihtiyacını desteklediğini ve bu desteğin mutlu bir aile yaşamı için kritik olduğunu vurgulamışlardır. Ayrıca bazı toplumların eğitim yolu ile kendilerini geliştirdiği, daha fazla eğitim alan bireylerin toplumun diğer üyeleri tarafından daha fazla kabul gören aidiyet hissiyatı verebileceğini ifade etmişlerdir. Çalışmalarında bireylerin aylık geliri ne kadar az olur ise ait olma hissi o kadar fazla olduğunu hissettiklerini de ortaya koymuşlardır. Deibert ve Walsh (1981, s. 170) ise çalışmalarında öğrencilerin bilişsel öğrenmelerini gerçekleştirdiklerinde ya da bu ihtiyaçları tatmin edildiğinde grup içerisinde kendilerini güvende hissettikleri ve dolayısı ile çoğunluğun ait olma duygusuna sahip olduğunu çalışma sonuçlarında ortaya koymuşlardır.

\section{Sayg1 İhtiyaçları}

Maslow insanoğlunun gündelik hayattaki deneyimleri ile gündelik yaşamda belli bir yapıya sahip olduğunu belirtmişlerdir (Zalenski ve Raspa, 2006, s. 1121). Bu açıdan sayg1 ihtiyac1; bireylerin kurum (işletme veya yer) içinde veya dışında prestije sahip olmaları ile ifade edilebilir (Brenner vd., 1971, s. 360). İnsanlar hedeflerini gerçekleştirdiklerinde rahatlık hissiyatları bu seviyeye gelmelerini sağlar. Bu durum aynı zamanda bireyin kendisinden ve başka bireylerden gelen başarı seviyesi veya statüsünü ortaya koymaktadır (Zakaria ve Malek, 2014, s. 44). Yani bireyin başarısı, güven düzeyi, saygısı ve ait olduğu grup içerisinde sahip olduğu statüsünden doğan memnuniyet hissiyatı gibi durumlar özgüven (sayg1) ihtiyacını karşılanmasında kilit rol oynamaktadır (Urwiler ve Frolick, 2008, s. 84).

$\mathrm{Bu}$ aşamada saygınlık, başarı ve başkaları tarafından tanınma ile birlikte benlik saygısının gerçekleşmesi söz konusu olabilmektedir (Cao vd., 2012, s. 171). Milheim (2012, s. 165-166) öğrenciler üzerinde yapmış olduğu çalışmasında bu aşamada bireylerin saygin, değerli hissetmeleri ve performanslarına yönelik güven duygusunu kazanmaları gerektiğini ifade etmiştir.

\section{Kendini Gerçekleştirme}

Gelişmeye yönelik bireysel yeteneklerin optimal gelişiminde ve yerine getirilmesinde iyi bir yaşam üzerine yapılan vurgu kendini gerçekleştirmenin en iyi ahlaki gelişim sürecidir (Laceulle, 2018, s. 95). Bu açıdan Maslow ve arkadaşları psikolojik sağlığı mükemmel olan insanları incelemeye karar vermişlerdir. Kriterleri negatif ve pozitif olarak ele almışlardır. Onlar olumlu kriteri kendini gerçekleştirme durumu olduğunu belirtmişlerdir. Bunun kesin olarak tanımlanması zordur (Weinberg, 2005, s. 315). Ancak bu zorluğun belirli sınırlar çerçevesinde araştırılması literatüre farklı bir bakış açısı kazandırabilecektir.

Kısmi ihtiyaçlar tatmin edildiğinde birey kendini ve çevresini tam olarak tecrübe etmesi ile daha üst düzey bir gelişme için kendisini rahat hissedebilecektir (Sengupta, 2011, s. 102). Bu açıdan Maslow uygulamasında kendini gerçekleştirme ihtiyacını sınırlandırmamıştır. Ancak fizyolojik ihtiyaçlarının baskın olduğu motivasyon aşamasını sınırlandırmıştır (Koltko-Rivera, 2006, s. 307). O halde kendini gerçekleştiren kişiyi karakterize eden değerler; bireyin kendi gereksinimlerine ulaşmadan önce karşılanması 
gereken evrensel temel insani ihtiyaçları (güvenlik, aidiyet ve saygı gibi) ile oluşabildiği anlaşılmaktadır (Podeschi, 1983, s. 96-97).

Herhangi bir birey bir öğrenci yada arkadaş ile çalışırken daha önce olduğu durumdan daha aktif ve uyarlanabilir koşullar olușturur ise bu kontrol edilebilir bir ilerlemedir (Murray vd., 1961, s. 576). College (1983, s. 84) öğrenciler üzerinde yaptığı çalışmasında iç kontrol konusunda güçlü bir inanca sahip olan bireylerin; fizyolojik, güvenlik, aidiyet, saygı ve kendini gerçekleştirme ihtiyaçlannndan büyük ölçüde memnuniyet duyduklarını çalışma sonuçlarında ortaya koymuştur. Ayrıca çalışmada şans faktörüne güçlü inancı olan öğrencilerin bu ihtiyaçlarından çok az tatmin oldukları ve başkalarının kontrolüne güçlü bir inancı olan öğrencilerin ise fizyolojik, güvenlik ve saygı ihtiyaçları konusunda çok az tatmin olduklarını uygulama sonucunda ifade etmiştir. Saunders ve diğerleri (1998, s. 20) ise çalışmalarında psikolojik iyilik halinde varyansa tek katkı sağlamayan değişken kendini gerçekleştirme olduğunu çalışma sonuçlarında ortaya koymuşlardır. Ayrıca çalışmalarında ihtiyaçlar hiyerarşisi ölçeğinin depresyonda gerileme, kaygı ve öfke ifadeleri ile ölçek içerisindeki en büyük farkı açıkladıklarını ifade etmişlerdir.

\section{Hipotezlerin Oluşturulması}

Araştırma hipotezleri oluşturulurken daha evvel konu ile ilgikli yapılan araştırmalar incelenmiş ve teorik çerçevede ifade edilen kavramlar dikkate alınmıştır. Belirli bir temeli olan teorik araştırmaların bulguları, verilerden oluşan ve veriler üzerinde test edilen hipotezlerden oluşur. Hipotez üretme araştırmaları, değerlendirme ve gelişim araştırmaları gibi önemli bir hipotez testine sahiptirler (Gilgun, 1992 , s. 116). Hipotez testleri uygulamalı psikolojik araştırmalarda veri analizlerinin temelini oluşturmaktadır (Loftus, 1991, s. 1). Bu durumda hipotezlerin destek bulmasında bir veya daha fazla durum söz konusu olabilir. Bunlara örnek olarak Maslow’un iddia ettiği teori doğru olabilir, araştırma normları ile gelenekler doğru olabilir ve hipotezlerin test edilmesinde kullanılan metodolojinin yeterli olması hipotezlerin destek bulmalarını sağlayabilir (Mathes, 1981, s. 71). Bu açıldan araştırma hipotezlerinde diğer teoremlerin de ifade edilmesinde doğru sonuçların test edilmesi için aşağıdaki hipotezler oluşturulmuştur.

H1: Genc girişimci adaylarmm kendine özgü olmalarn girişimcilik niyetlerini pozitif yönde etkiler.

H2: Genç girişimci adaylarmm çeşitlilik aramalar girişimcilik. niyetlerini pozitit yönde etkiler.

H3: Genc girişimci adaylarmm fikir liderliği yapmalar girnşimcilik niyetlerini poz̧itif yönde etkiler.

H4: Genc girișimci adaylarmm girişimcilik niyetleri firsyolojik ibtiyaçlarm pozitif yönde etkiler.

H5: Genc girişimci adaylarmm girişimcilik niyetleri güvenlik ibtiyaçlarm pozitif yönde etkiler.

H6: Genc girişimci adaylarnnn girişimcilik niyetleri ait olma ibtiyaçlarm pozitififyönde etkiler.

H7: Genc girişimci adaylarmmn girișimcilik niyetleri sayg ibtiyaçlarm požitifyönde etkiler.

H8: Genç girişimci adaylarmm girişimcilik niyetleri kendilerini gerçeklesstirme ibtiyaçlarm pozitifyönde etkiler.

\section{Yöntem}

\section{Araştırma Modeli}

Çalışmada araştırma modeli oluşturulurken daha önce gerçekleştirilen çalışmalardan faydalanılmıştır. Araştırmada genç bireylerin yaşam tarzları, girişimcilik niyetleri ve Maslow'un ihtiyaçlar hiyerarşisine yönelik ölçekler nicel veriler ışığında geçerlilik ve güvenilirlik analizleri yapılmış ve sonuçlar literatür eşliğinde yorumlanmışır (Olufunso, 2010, s. 96; Yang, 2004, s. 203; Taormina ve Gao, 2013, s. 176). Araştırmada Yapısal Eşitlik Modeli uygulanarak değişkenler buna göre yorumlanmıştır. 


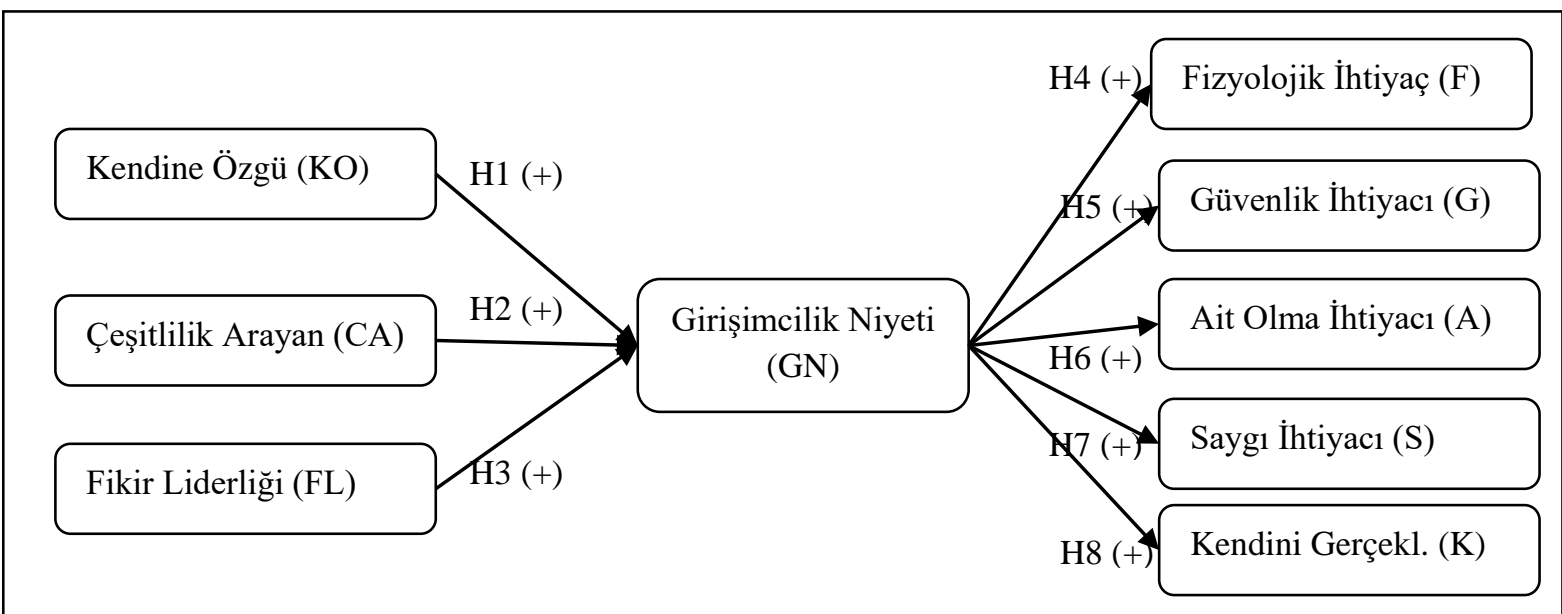

Kaynak: Yang, 2004; Olufunso, 2010; Taormina ve Gao, 2013

Şekil 1. Uygulama Modeli

Şekil 1'de yer alan araştırma modeli incelendiğinde; genç girişimci adaylarının yaşam tarzlarının girişimcilik niyeti üzerindeki etkileri ve girișimcilik niyetlerinin de Maslow’un oluşturduğu ihtiyaçlar hiyerarşisi üzerindeki etkileri ölçülmeye çalışılmaktadır.

\section{Araştırmanın Amacı ve Önemi}

Günümüzde gelişen ve değişen dünya koşullarında genç bireyler aldıkları eğitim doğrultusunda gündelik hayata adapte olabilmekte, yeni ve yaratıcı girişimler ile hem kendilerine hem çevrelerine hem de ülke ekonomisine katkıda bulunabilmektedirler. Bu açıldan çalışmada eğitimi devam eden veya eğitimini belli bir süreye kadar tamamlamış olan (5 yıla kadar) bireylerin yaşam tarzı faktörlerinin (kendine özgü olan, çeşitlilik arayan ve fikir liderliği yapan) girişimcilik niyetleri üzerinde ne gibi etkilerinin olduğu ve girişimcilik niyetlerinin de Maslow'un oluşturduğu ihtiyaçlar hiyerarşisi (fizyolojik, güvenlik, ait olma, sayg1 ve kendini gerçekleştirme) üzerinde nasıl bir etkiye sahip olduğunun ortaya koyulması amaçlanmaktadır. $\mathrm{Bu}$ açıdan ortaya çıkacak sonuçlar ile literatüre farklı bir bakış açısının kazandırılması amaçlanmaktadır.

\section{Evren - Örneklem}

Uygulamanın bulguları Türkiye'de 2019 yllı içerisinde Gümüşhane ve Bayburt illerinde yaşayan 343 genç birey üzerinde (henüz eğitimi devam eden veya 5 yıla kadar eğitimini tamamlamış olan) elektronik anket yöntemi kullanılarak elde edilmiştir. Araştırmada her iki ilde tespit edilen ortalama 1000 kişi için \% 95 güven seviyesi ve $\% 5$ hata payında ( $\mathrm{n}=\mathrm{N} \mathrm{t}^{2} \mathrm{p} \mathrm{q} / \mathrm{d}^{2}(\mathrm{~N}-1)+\mathrm{t}^{2} \mathrm{p}$ q' formülü yardımı ile) evrenin örneklem büyüklüğü 278 olduğu tespit edilmiştir (Baş, 2008, s. 87-88). Araştırmada anket yönteminin elektronik olarak uygulanmasında, günümüz genç bireylerin teknolojinin de gelişmesine bağlı olarak internet, sosyal medya gibi (facebook, whatsapp, e-posta vb.) uygulamalar1 fazla kullanıyor olmalarından ötürü tercih edilmiştir. Araştırmanın sınırları aşağıdaki gibi ifade edilebilir.

- Araştırmada sadece genç bireyler dikkate alınmış, bireylerin aile yapıları, örf, adet, gelenek, dini inanç ve diğer ekonomik, sosyo-kültürel değerler tam anlamı ile incelenememiştir.

- Çalışma gerçekleştirilirken bireylerin kaygıları (işsizlik, geleceğe dair mesleki kaygıları, ailesel kaygılar gibi) dikkate alınamamıştır. Dolayısı ile bireylerin psikolojik durumları ölçülememiştir.

- Uygulama anketleri gerçekleştirilirken (elektronik olarak gerçekleştirilmiştir) bireylerin motivasyon faktörü gözlemlenememiştir.

\section{Veri Toplama Araçları}

Çalışmanın ölçeği, maddeler ve yararlanılan kaynaklar aşağıda Tablo 1'de gösterilmiştir. 
Tablo 1. Araştırmanm Ölçekleri

\begin{tabular}{lcl}
\hline \multicolumn{1}{c}{ Ölçek } & Maddeler & \multicolumn{1}{c}{ Kaynak } \\
\hline Yaşam Tarzı & 11 & Yang, 2004, s. 203 \\
Girişimcilik Niyeti & 6 & Olufunso, 2010, s. 96 \\
\hline İhtiyaçlar Hiyerarşisi & 26 & Taormina ve Gao, 2013, s. 176-177 \\
\hline
\end{tabular}

Araştırmada Yang'ın (2004, s. 203) çalışmasında bireylerin internet reklamlarına yönelik tutumlarında oluşturulan yaşam tarzı segmentlerinden 11 adet soru çalışmaya yaşam tarzı ölçeği olarak uyarlanmıştır. Olufunso'nun (2010, s. 96) girişimcilik niyeti ölçeğinden 6 adet soru ve Taormina ve Gao'nun (2013, s.176-177) Maslow’un ihtiyaçlar hiyerarşisi çalışmalarından 26 adet soru çalışma ölçeğine uyarlanmıştır. Çalışma ile ilgili uygulanan analizler ve elde edilen sonuçlar aşağıda detaylı olarak verilmiştir.

\section{Verilerin Analizi}

Gerçekleştirilen çalışmanın değişkenlerine normallik testi uygulanmış ve demografik veriler ile değişkenler arasında genel itibari ile (Skewness ve Kurtosis /çarpiklık ve basıklık değerlerinde) normal dağılım gözlemlenmiştir. Araştırmada açıklayıcı faktör analizi uygulanmış değişkenler 9 faktör altında toplanmıştır. Her bir faktörün geçerliliği Tablo 3’te ifade edilmiştir. Araştırmanın güvenirliğini ortaya koyan Cronbach Alpha = ,946 ve geçerliliğini ortaya koyan $\mathrm{KMO}=, 890$ olarak hesaplanmıştır. Çalışmada 9 faktörün açıklanan varyansa toplam katkısı ise \% 68, 234 olduğu gözlemlenmiştir. Elde edilen sonuçlar çalışma ölçeğinin geçerli ve güvenilir sonuçlar oluşturduğu anlaşılmaktadır (Moosmayer, 2012, s. 164).

\section{Bulgular}

Araştırmanın demografik bulgularına Tablo2'de yer verilmiştir. Tablo2'de uygulamaya katılan genç bireylerin cinsiyet, gelir, yaş ve en son mezuniyetlerinin ne olduğuna dair bilgiler yer almaktadır.

Tablo 2. Demografik Bulgular

\begin{tabular}{|c|c|c|c|c|c|}
\hline Cinsiyet & $f$ & $\%$ & Gelir & $f$ & $\%$ \\
\hline Kadın & 177 & 51,6 & 2000 TL veya alt1 & 209 & 60,9 \\
\hline Erkek & 166 & 48,4 & 2001-4000 TL & 81 & 23,6 \\
\hline \multirow[t]{3}{*}{ Toplam } & 343 & 100,0 & 4001-6000 TL & 36 & 10,5 \\
\hline & & & 6001 TL ve üzeri & 17 & 5,0 \\
\hline & & & Toplam & 343 & 100,0 \\
\hline Ëgitim & $f$ & $\%$ & Yaş & $f$ & $\%$ \\
\hline İlköğretim & 5 & 1,5 & 18 veya altı & 15 & 4,4 \\
\hline Ortaokul veya Lise & 128 & 37,3 & $19-20$ & 69 & 20,1 \\
\hline Önlisans & 78 & 22,7 & $21-22$ & 69 & 20,1 \\
\hline Lisans & 88 & 25,7 & $23-24$ & 79 & 23,0 \\
\hline Lisansüstü & 44 & 12,8 & $25-26$ & 36 & 10,5 \\
\hline \multirow[t]{2}{*}{ Toplam } & 343 & 100,0 & 27 yaş ve üzeri & 75 & 21,9 \\
\hline & & & Toplam & 343 & 100,0 \\
\hline
\end{tabular}

Tablo 2'de verilen bilgiler incelendiğinde araştırmaya katılan genç bireylerin çoğu kadınlardan (177 kişi - \%51,6) oluşmaktadır. Uygulamada çoğu bireyin aylık geliri 2000TL veya altında (209 kişi - \%60,9) olduğu görülmektedir. Ayrıca genç bireylerin birçoğunun en son mezuniyetleri $(128$ kişi - \%37,3) ortaokul veya lise olup en fazla 23 veya 24 yaş $(79$ kişi - \%23,0) aralığındaki bireyler olduğu gözlemlenmektedir.

Uygulamalarda güvenirliğin geçerliliğin altında yer aldığını ifade eden araştırmacılar bile çalışmalarının güvenilirliğini dikkate almaktan kaçınmazlar. Bu açıdan hiçbir geçerlilik katsayısı ve hiçbir faktör analizi ölçüm hatalarındaki büyüklüğün uygun olup olmadığının tahminini ortaya koymadan yorumlanamaz. $\mathrm{O}$ halde deneysel analizlerin ağırlıklı değerlerini ortaya koyulurken ideal olan ölçekler önemli bir Alpha'ya sahip olmalidirlar (Cronbach, 1951, s. 297/332). 
Tablo 3. Ölçeklere Illiskkin Güvenirlik Analizi Sonuclar

\begin{tabular}{llccc}
\hline & \multicolumn{1}{c}{ Faktörler } & Maddeler & $\begin{array}{c}\text { Cronbach's } \\
\text { Alpha }\end{array}$ & KMO \\
& Kendine Özgü Olmak (KO) & 4 & 0,713 & 0,702 \\
\multirow{3}{*}{ Yaşam Tarzı Ölçeği } & Çeşitlilik Aramak (CA) & 4 & 0,855 & 0,746 \\
& Fikir Liderliği Yapmak (FL) & 3 & 0,824 & 0,720 \\
\hline Girişimcilik Niyeti Ölçeği & Girişimcilik Niyeti (GN) & 6 & 0,874 & 0,852 \\
\hline \multirow{4}{*}{ İhtiyaçlar Hiyerarşisi Ölçeği } & Fizyolojik İhtiyaçlar (F) & 5 & 0,830 & 0,805 \\
& Güvenlik İhtiyacı (G) & 5 & 0,858 & 0,726 \\
& Ait Olma İhtiyacı (A) & 5 & 0,859 & 0,810 \\
& Saygı İhtiyacı (S) & 5 & 0,907 & 0,805 \\
\hline & Kendini Gerçekleştirme (K) & 6 & 0,896 & 0,874 \\
\hline
\end{tabular}

Araştırma ölçeğinde oluşan sonuçlar dikkate alındığında bireylerin kendine özgü olmalarını (KO) gösteren değişkenin güvenilirliği 0,713 (Cronbach's Alpha) ve geçerliliği 0,702 (KMO) olduğu, genç bireylerin çeşitlilik aramalarını (CA) ortaya koyan değisskenin güvenilirliği 0,855 (Cronbach's Alpha) ve geçerliliği $0,746(\mathrm{KMO})$ olduğu, genç girişimci adayı bireylerin fikir liderliği (FL) yapma değişkenleri güvenilirliği 0,824 (Cronbach's Alpha) ve geçerliliği 0,720 (KMO) olduğu, bireylerin girişimcilik niyeti (GN) değişkeninin güvenilirliği 0,874 (Cronbach’s Alpha) ve geçerliliği 0,852 (KMO) olduğu, genç bireylerin fizyolojik ihtiyaçlarını (F) veren değişkenin güvenilirliği 0,830 (Cronbach's Alpha) ve geçerliliği 0,805 (KMO) olduğu, genç girişimci adaylarının güvenlik ihtiyacını $(\mathrm{G})$ veren değişkenin güvenilirliği 0,858 (Cronbach's Alpha) ve geçerliliği 0,726 (KMO) olduğu, bireylerin ait olma (A) ihtiyaçlarını oluşturan değişkenin güvenilirliği 0,859 (Cronbach's Alpha) ve geçerliliği 0,810 (KMO) olduğu, genç bireylerin sayg1 ihtiyaçlarını (S) ortaya koyan değişkenin güvenilirliği 0,907 (Cronbach's Alpha) ve geçerliliği 0,805 (KMO) olduğu ve bireylerin kendini gerçekleştirme (K) ihtiyaçlanını veren değişkenin güvenilirliği ise 0,896 (Cronbach's Alpha), geçerliliği ise 0,874 (KMO) olduğu gözlemlenmektedir. Bu sonuçlar uygulama ölçeğinde yer alan verilerin kabul edilebilir değişkenler ortaya koyduklarını göstermektedir (Chang, 2008, s. 280; Valikhani, Hashempoor ve Vastegani, 2015, s. 8; Battal ve Durmuş, 2015, s. 75; Kim, 2010, s. 116; Sevari, 2017, s. 10). Ölçüm modelinde verilen değişkenlerin faktör ve güvenilirlik analizleri sonuçları aşağıda Tablo 4, Tablo 5 ve Tablo 6'da ifade edilmiştir.

Tablo 4. Yasam Tarzı Ölceğinin Faktör Analizi Sonuclar

\begin{tabular}{|c|c|c|c|c|c|}
\hline & Faktörler & $\begin{array}{l}\text { Alpha } \\
\text { (Yüzde) }\end{array}$ & $\begin{array}{c}\text { Açılklanan } \\
\text { Varyansı (\%) }\end{array}$ & Özdeğer & $\begin{array}{l}\text { Faktör } \\
\text { Yükleri }\end{array}$ \\
\hline KO1 & Girişimciliği sevdiğin için yaparım. & & & & 0.61 \\
\hline $\mathrm{KO} 2$ & Her zaman ne istersem onu yaparım. & ,713 & 38,995 & 3,245 & 0.75 \\
\hline $\mathrm{KO} 3$ & Genellikle plansız girişimcilik yaparım. & & & & 0.81 \\
\hline KO4 & Girişimciliğin tek amacı para kazanmaktır. & & & & 0.76 \\
\hline CA1 & Her zaman yeni ve benzersiz bir şey denerim. & & & & 0.77 \\
\hline CA2 & Günün koşullarına uygun girişimleri severim. & & & 2,659 & 0.90 \\
\hline CA3 & Yeni girişimsel faaliyetlerden etkilenirim. & 855 & 20,136 & & 0.87 \\
\hline CA4 & Günün şartlarına uygun hareket etmek zarar vermez. & & & & 0.81 \\
\hline FL1 & Birileri ile konuşurken onları kolayca etkileyebilirim. & & & & 0.85 \\
\hline FL2 & $\begin{array}{l}\text { Arkadaşlarım genellikle kendi kararlarını } \\
\text { veremediklerinde bana danısırlar. }\end{array}$ & 824 & 8,012 & 2,215 & 0.87 \\
\hline FL3 & Başarılı olmak için güçlü bir isteğim var. & & & & 0.86 \\
\hline
\end{tabular}

Kaiser-Meyer-Olkin Measure of Sampling Adequacy $=, 860 /$ Bartlett's Test $=1789,435 /$ Cronbach's Alpha $=, 878$

Araştırma sonuçları faktör yükleri açısından değerlendirildiğinde; genç girişimci adaylarının kendilerine özgü olmalarında ölçeğe en fazla katkıyı KO3 (0.81) sağlamaktadır. Yani genç girişimcilerin genellikle girişimciliği plan yapmadan yerine getirdiklerini ifade ettikleri anlaşılmaktadır. Genç bireylerin çeşitlilik aramalarına yönelik değişkende en fazla katkıyı CA2 (0.90) oluşturmaktadır. Burada ise günün koşullarına uygun olan girişimlerin sevildiği ifade edilmiştir. Fikir liderliği açısından bakıldığında modele en fazla katk1 FL2 (0.87) tarafından sağlanmaktadır. Bu durumda genç girişimci adaylarının genellikle arkadaşlarının kendi kararlarını veremedikleri durumda onlara danıştıklarını ifade etmişlerdir. Elde edilen sonuç yaşam tarzı ölçeğinin uygulanabilir sonuçlar ortaya koyduğunu göstermektedir. Genç bireylerin girişimcilik niyeti ölçeğine ilişkin elde edilen verilere göre analiz sonuçları Tablo 5 'te ifade edilmiştir. 
Tablo 5. Girişimcilik Niyeti Faktör Analiz̨i Sonuclar

\begin{tabular}{|c|c|c|c|c|c|}
\hline & Faktörler & Alpha & $\begin{array}{c}\text { Açılklanan } \\
\text { Varyansı (\%) }\end{array}$ & Özdeğer & $\begin{array}{l}\text { Faktör } \\
\text { Yükleri }\end{array}$ \\
\hline GN1 & Mesleki hedefim girişimci olmaktır. & & & & 0.78 \\
\hline GN2 & $\begin{array}{l}\text { Bir şirkette çalışan olmak yerine girişimci olmayı tercih } \\
\text { ederim. }\end{array}$ & & & & 0.80 \\
\hline GN3 & Kendi işimin patronu olmak isterim. & 874 & 61,667 & 3,700 & 0.77 \\
\hline GN4 & Girişimci olmak için her şeyi yapmaya hazırım. & & & & 0.84 \\
\hline GN5 & Gelecekte bir firma kurmaya kararliyım. & & & & 0.79 \\
\hline GN6 & İşime önümüzdeki beş yıl içerisinde başlayacağım. & & & & 0.74 \\
\hline
\end{tabular}

Girişimcilik niyeti açısından bakıldığında modele en çok katk1 GN4 (0.84) seçeneğinin sağladığ1 görülmektedir. $\mathrm{Bu}$ seçenek ile bireylerin girişimci olmak için her şeyi yapmaya hazır oldukları anlaşılmaktadır. Girişimcilik niyeti ölçeği sonuçları çalışmanın uygulanabilir olduğunu ortaya koymaktadır. Genç bireylerin Maslow'un ihtiyaçlar hiyerarşisine yönelik verdikleri yanıtların faktör ve güvenilirlik analizleri sonuçları Tablo 6'da verilmiştir. Tablo 4, Tablo 5 ve Tablo 6'ya ilişkin elde edilen sonuçlar yorumlanmiştır.

Tablo 6. Maslow'un İhtiyaçlar Hiyerarşisi Faktör Analiz̧ Sonuçar

\begin{tabular}{|c|c|c|c|c|c|}
\hline & Faktörler & Alpha & $\begin{array}{c}\text { Açıklanan } \\
\text { Varyansı (\%) }\end{array}$ & $\begin{array}{c}\text { Özdeğe } \\
\quad r\end{array}$ & $\begin{array}{l}\text { Faktör } \\
\text { Yükleri }\end{array}$ \\
\hline F1 & Genel olarak fiziksel sağlığım iyidir. & 830 & 18,161 & 4,722 & 0.71 \\
\hline $\mathrm{F} 2$ & Genel olarak tükettiğim su kalitelidir. & & & & 0.79 \\
\hline $\mathrm{F} 3$ & Gündelik hayatta tükettiğim yiyecekler kalitelidir. & & & & 0.87 \\
\hline $\mathrm{F} 4$ & $\begin{array}{l}\text { Gündelik hayatta uyku yeterliliğim konusunda kendimi rahat } \\
\text { hissederim. }\end{array}$ & & & & 0.76 \\
\hline F5 & Her gün soluduğum hava oldukça kalitelidir. & & & & 0.73 \\
\hline G1 & Yaşadığım evde (dairede) oldukça güvendeyim. & 858 & 13,275 & 3,452 & 0.81 \\
\hline G2 & Yaşadığım mahallede (köyde) oldukça güvendeyim. & & & & 0.83 \\
\hline G3 & $\begin{array}{l}\text { Yaşadığım yerde herhangi bir hastalığa yakalanma ihtimalim } \\
\text { düşüktür. }\end{array}$ & & & & 0.78 \\
\hline G4 & Kanunlar benim güvenli yaşamamı sağlar. & & & & 0.79 \\
\hline G5 & İhtiyacım olduğunda para kazanabilirim. & & & & 0.80 \\
\hline A1 & Arkadaşlarım ile olan ilişkilerim kalitelidir. & 859 & 12,849 & 3,341 & 0.82 \\
\hline A2 & Arkadaşlarım ile mutluluğumu paylaşabilirim. & & & & 0.84 \\
\hline A3 & Ailem ile samimi paylaşımlar yaparım. & & & & 0.79 \\
\hline A4 & Yapacağım işlerde ailem ile birlikte hareket ederim. & & & & 0.71 \\
\hline A5 & Genellikle çevremdeki insanlar tarafindan hoş karşılanırım. & & & & 0.85 \\
\hline S1 & Başkaları tarafindan genellikle takdir edilirim. & 907 & 12,49 & 3,247 & 0.87 \\
\hline S2 & Birçok insan bana onur verir. & & & & 0.90 \\
\hline S3 & Birçok insan bana yüksek derecede sayg1 gösterir. & & & & 0.81 \\
\hline S4 & Kendime karşı saygı duyarım. & & & & 0.84 \\
\hline S5 & Kendimden oldukça eminim. & & & & 0.84 \\
\hline K1 & En içten arzularımın farkındayım. & 896 & 12,276 & 3,192 & 0.82 \\
\hline K2 & Davranışlarım her zaman kendi değerlerime göredir. & & & & 0.82 \\
\hline K3 & İstediğim zaman yapmak istediklerimi yaparım. & & & & 0.77 \\
\hline K4 & $\begin{array}{l}\text { Yapacağım işler konusunda kendimi tamamen tatmin ettiğimi } \\
\text { hissederim. }\end{array}$ & & & & 0.84 \\
\hline K5 & Her zaman olmak isteğim kişiyim. & & & & 0.87 \\
\hline K6 & Tüm yeteneklerime yetişirim. & & & & 0.75 \\
\hline
\end{tabular}

Kaiser-Meyer-Olkin $=, 899 /$ Bartlett's Test $=6414,251 /$ Cronbach's Alpha $=, 938$

Bireylerin fizyolojik ihtiyaçları açısından bakıldığında modele en fazla katkıyı F3 (0.87) sağlamaktadır. Burada ise bireylerin gündelik hayatta tükettikleri yiyeceklerin kaliteli olduğu anlaşılmaktadır. Güvenlik ihtiyacı açısından bakıldığında modele en fazla katk1 G2 (0.83) seçeneğinden sağlandığı gözlemlenmektedir. $\mathrm{Bu}$ seçenek ile bireyler yaşadıkları mahallede (köyde) oldukça güvende olduklarını hissettiklerini ifade etmişlerdir. Bireylerin ait olma ihtiyaçları açısından değerlendirildiğinde en çok katk1 A5 (0.89) seçeneğinden gelmektedir. Bu seçenekte ise bireylerin genellikle çevrelerindeki insanlar tarafindan hoş 
karşılandıkları anlaşılmaktadır. Saygı ihtiyacı dikkate alındığında en fazla katk1 S2 (0.90) seçeneğinden sağlandığ1 görülmektedir. $\mathrm{Bu}$ tercihte ise birçok insanın genç girişimci adaylarına onur verdiği anlaşılmaktadır. Bireylerin kendilerini gerçekleştirme seçenekleri açısından bakıldığında ise en fazla katk1 K5 (0.87) seçeneğinin olduğu görülmektedir. Bu seçenekte genç girişimci adayları her zaman olmak istedikleri kişi olduklanını ifade etmişlerdir.

Araştırma sonuçlarında her ölçeğin ayrı ayrı açıklanan varyansa toplam katkıları sırası ile fikir liderliğı yapmak (FL-73,997), sayg1 ihtiyacı (S-73,240), çeşitlilik aramak (CA-70,99), kendini gerçekleştirme (K66,354), ait olma (A-64,632), güvenlik ihtiyac1 (G-64,214), girişimcilik niyeti (GN-61,667), fizyolojik ihtiyaç (F-60,129) ve kendine özgü olmak (KO-54,193) olarak sıralanmıştır.

\section{Uygulanan Modelin Yapısal Eşitliğe Uygunluğunun Sonuçları ve Yorumlanması}

Uygulanan ölçüm modelinin sonuçlarını test etmek için AMOS 24 paket programından yararlanılmış olup Yapısal Eşitlik Modeli’ni ifade eden (ölçüm modeli) sonuçlar aşağıda gösterilmiştir.

Tablo 7. Modelin Uyum İyiliüi Değerleri

\begin{tabular}{|c|c|c|}
\hline Índeksler & Referans Dĕ̆eri & Ölçüm Modeli \\
\hline$\overline{\mathrm{CMIN} / \mathrm{DF}}$ & $0<\chi^{2 / s d} \leq 5$ & 3,034 \\
\hline RMR & $<, 1$ & 0759 \\
\hline IFI & $>, 90$ & 911 \\
\hline TLI & $>, 90$ & 903 \\
\hline CFI & $>, 90$ & 910 \\
\hline RMSEA & $0,05 \leq$ RMSEA $\leq 0,08$ & 077 \\
\hline AGFI & $>, 90$ & 820 \\
\hline GFI & $>, 90$ & ,759 \\
\hline NFI & $>, 90$ & 880 \\
\hline RFI & $>, 90$ & 857 \\
\hline
\end{tabular}

Uygulama sonuçları genel itibari ile değerlendirildiğinde CMIN/DF = 3,034, RMR = ,759, IFI = ,911, TLI = ,903, CFI = ,910, RMSEA = ,077, AGFI = ,820, GFI = 759, NFI $=880$ ve RFI $=, 857$ olarak hesaplanmıştır. YEM sonuçları genel olarak değerlendirildiğinde modelin kabul edilebilir ve değişkenlerin uyumlu bir düzeyde olduğunu ortaya koymaktadır (Dalvi, Haery, ve Ebrahimi, 2013, s. 151; Valentine ve Rittenburg, 2004, s. 6; Huang, Ho, Smith ve Chen, 2006, s. 431; Baer vd., 2018, s. 1773; Valentine, Godkin, Fleischman, Kidwell ve Page, 2011, s. 515-517; Chang, 2008, s. 281; Qiu, Wang ve Yang, 2015, s. 186). Uygulamanın Regression ölçüm modeli sonuçları aşağıda Tablo 6'da ifade edilmiştir.

Tablo 8. Hipotez Testi Sonuclar

\begin{tabular}{lcccc}
\hline Modeldeki Illiskilendirmeler & Hipotez & Estimate & $\boldsymbol{P}$ & Açklamalar \\
\hline $\mathrm{KO} \rightarrow \mathrm{GN}$ & $\mathrm{H} 1$ &, 592 & 0,00 & Kabul \\
$\mathrm{CA} \rightarrow \mathrm{GN}$ & $\mathrm{H} 2$ &,- 105 &, 401 & Red \\
$\mathrm{FL} \rightarrow \mathrm{GN}$ & $\mathrm{H} 3$ &, 471 & 0,00 & Kabul \\
$\mathrm{GN} \rightarrow \mathrm{F}$ & $\mathrm{H} 4$ &, 265 & 0,00 & Kabul \\
$\mathrm{GN} \rightarrow \mathrm{G}$ & $\mathrm{H} 5$ &, 393 & 0,00 & Kabul \\
$\mathrm{GN} \rightarrow \mathrm{A}$ & $\mathrm{H} 6$ &, 568 & 0,00 & Kabul \\
$\mathrm{GN} \rightarrow \mathrm{S}$ & $\mathrm{H} 7$ &, 485 & 0,00 & Kabul \\
\hline $\mathrm{GN} \rightarrow \mathrm{K}$ & $\mathrm{H} 8$ &, 522 & 0,00 & Kabul \\
\hline
\end{tabular}

AMOS Regression ölçüm modeli sonuçları incelendiğinde; genç bireylerin kendine özgü olmaları ile girişimcilik niyetleri arasında anlamlı ilişkiler elde edilmiştir. Bireylerin çeşitlilik aramaları ile girişimcilik niyetleri arasında anlamlı bir ilişki elde edilmemiştir. Genç bireylerin fikir liderliği yapmaları ile girişimcilik niyetleri arasında anlamlı ilişkiler bulunmuştur. Ayrıca bireylerin girişimcilik niyetleri ile fizyolojik ihtiyaçları, güvenlik ihtiyaçları, ait olma ihtiyaçları, sayg1 ihtiyaçları ve kendini gerçekleştirme ihtiyaçları arasında anlamlı ilişkiler olduğu görülmektedir. Uygulamanın Yapısal Eşitlik Modeli sonuçları aşağıda şekil 2'de ifade edilmiştir. 


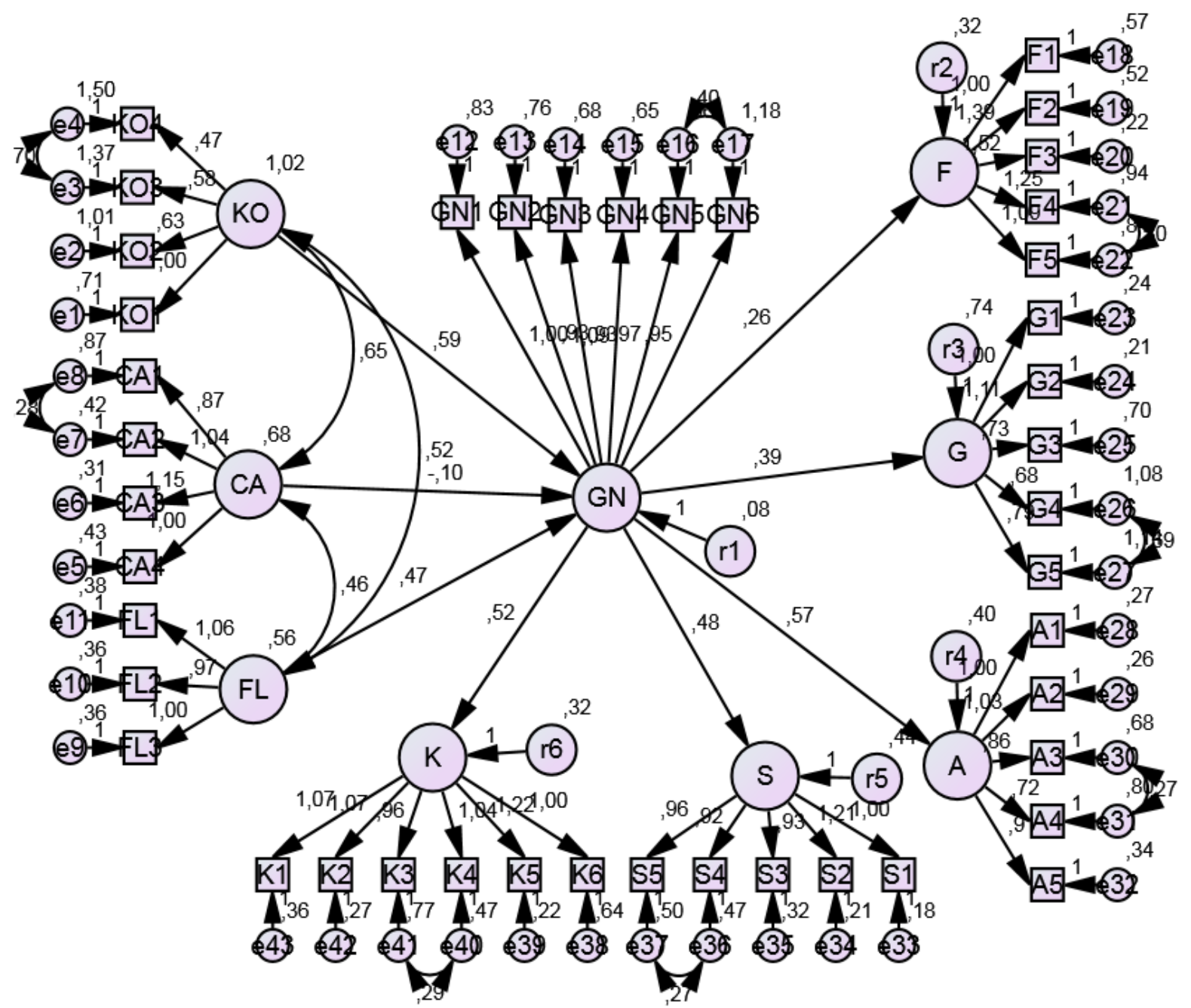

Şeki12. Uygulama Modelinin Yapısal Eşitlike Sonuçar

Araştırma şekil 2'de verilen sonuçlar genel olarak değerlendirildiğinde; çalışma hipotezlerinden h1, h3, h4, h5, h6, h7 ve h8 hipotezleri kabul edilmiştir. Çalışmada sadece h2 hipotezi reddedilmiştir. Yani bireylerin yaşam tarzlarından çeşitlilik aramaları ile girişimcilik niyeti arasında anlamlı ilişkiler olmadığı sonuçlarına ulaşılmıştır (araştırma modeli sonuçlarında -,10 olarak elde edilmiş olsa da $\mathrm{p}=, 401$ olmasından ötürü anlamsız kabul edilmektedir).

Araştırmada H1 hipotezine göre bireylerin kendine özgü olmaları girişimcilik niyetlerini pozitif yönde (,59) etkilemektedir. H3 hipotezine göre genç bireylerin fikir liderliği yapmaları girişimcilik niyetlerini pozitif olarak $(, 47)$ etkilemektedir. H4 hipotezinde ise kişilerin girişimcilik niyetleri fizyolojik ihtiyaçlarını pozitif yönde $(, 26)$ etkilemiştir. H5 hipotezinde bireylerin girişimcilik niyeti güvenlik ihtiyacını pozitif olarak $(, 39)$ etkilemiştir. H6 hipotezinde genç bireylerin girişimcilik niyetleri ait olma ihtiyaçlarını pozitif yönde (,57) etkilemiştir. $\mathrm{H} 7$ hipotezinde uygulamaya katılan kişilerin girişimcilik niyetleri sayg1 ihtiyaçlarını pozitif $(, 48)$ etkilemiştir. H8 hipotezinde ise bireylerin girişimcilik niyetleri kendini gerekleştirme ihtiyaçlarını pozitif yönde etkilediği $(, 52)$ sonuçlarına ulaşılmıstır. Araştırma modelinde tam anlamı ile uyum sağlanabilmesi için bazı değişkenler arasında modifikasyon gerçekleştirilmiştir. Ayrıca çalışmada KO ve CA arasinda (,65), CA ve FL $(, 46)$ arasinda ve $\mathrm{KO}$ ve FL $(, 52)$ arasinda bir kovaryans olduğu gözlemlenmektedir.

\section{Tartışma, Sonuç ve Öneriler}

Günümüzde genç bireyler bilişim ve teknolojideki hızlı ilerlemeye bağlı olarak yaşam tarzları, girişimcilik niyetleri ve ihtiyaçları doğrultusunda hareket edebilmektedirler. Bireylerin bu hareketleri kapsamında araştırmada elde edilen sonuçlar literatür eşliğinde değerlendirilecek olur ise; bireylerin girişimcilik niyeti dikkate alındığında Gartner (2008) girişimciliği tek bir olgu olarak ifade etmenin doğru olmadığını ifade etmiştir. Shinnar ve diğerleri (2009) öğrencilerin davranışsal niyetleri ile girişimcilik 
eğilimleri arasında önemli ilişkiler olduğu sonucuna ulaşmışlardır. Atef ve Al-Balushi (2015) ise bireylerin girişimcilik için gerekli becerilere sahip olmaları gerektiğini ifade etmişlerdir. Yaşam tarzları açısından bakıldığında Yang (2004) ise çalışmasında bireyler arasındaki tutum farklılıklarının yorumlanmasına imkân sağladığını ifade etmiştir. Ayrıca kendine özgü hareket eden bireyler yaptıkları veya yapabilecekleri faaliyetleri sevdikleri, rahat davranış sergileyip plansız hareket edebilme özelliklerine sahip olduklarını ifade etmiştir. Bu sonuçlar araştırma sonuçlarını genel olarak destekler niteliktedir. Bu açıdan h1 hipotezi dikkate alındığında çalışmada bireylerin kendilerine özgü olmaları girişimcilik niyetlerini pozitif olarak etkilemiştir. Bu sonuç genç girişimci adayı bireylerin girişimciliği sevmeleri, rahat hareket etme kabiliyetleri ve plansız girişimde bulunabilme özellikleri girişimcilik niyetlerinde olumlu etkiler oluşturduğu gözlemlenmektedir. $\mathrm{Bu}$ sonuçlarda girişimciliği sevmenin ve rahat hareket edebilme durumlarının girişimcilik niyeti üzerine olumlu etki uyandırması normal bir olgudur. Ancak plansız girişim girişimcilik niyetini pozitif etkilemesi, girişimcilik niyetinde olan bireylerin genç yaşlara sahip olması veya fazla iş tecrübelerinin olamamasından kaynaklaniyor olabilir.

Qian (2013) uygulamasında çeşitliliğin girişimcilik firsatlarında algılamalar için önemli olduğunu vurgulamıştır. Lazear (2005) ise bireyin girişimci olma ihtimalinin kariyeri üzerinde sahip olduğu çeşitli rollerin sayısına ve eğitim hayatında edindikleri ile olumlu yönde ilişkili olduğunu ifade etmiştir. Araştırma modelinde bireylerin çeşitlilik araması girişimcilik niyeti üzerinde negatif bir etki uyandırdığı ifade edilse de çalışma sonuçlarında çeşitlilik arama ile girişimcilik niyeti arasında anlamsız bir ilişki olduğu görülmüştür. Elde edilen sonuç daha evvel gerçekleştirilen çalışmaları desteklememektedir. Bu sonuç genç girişimci adayı bireylerin henüz firsat algılamalarının tam anlamı ile belirginleşmediğini veya kariyer basamağına henüz atılmamış oldukları için çeşitli rollerde görev almadıklarını (genel itibari ile) yorumunu yaptrrabilmektedir.

Olson (2002) çalısmasında bireylerin iletişim becerilerinde fazla kişi ile olumlu diyalog gerçekleştirirlerse istenilen sonuçlara ulaşma da o düzeyde başarı gösterebileceklerini ifade etmiştir. Peters ve diğerleri (2008) gerçek girişimcilerin fikir üreterek problemleri ortaya çıkarabilen kişiler olduklarını vurgulamışlardır. Bavelas (1960) uygulamasında fikir liderliğinin bireylerin nitelikleri ve yetenekleri ile ilgili olduğunu dile getirmiştir. Welter ve diğerleri (2016) ise çalışmalarında girişimciliğin bir bütün olarak sistematik bir şekilde değerlendirilmesinin para kazanmanın yanında iş oluşturma fikri de dikkate alınarak girişimin zevkli ve faydalı yönlerinin ortaya koyulabileceğini ifade etmişlerdir. Elde edilen sonuç literatürü desteklemektedir. Araştırmada bireylerin fikir liderliği yapmalanı girişimcilik niyetlerini pozitif olarak etkilemiştir. O halde bu durum genç bireylerin fikir liderliği yaptıklarını sosyal ilişkilerinde diğer bireyleri yönlendirebilme yeteneklerine sahip olduklarını dolayısıyla girişimcilik niyetlerinde pozitif etkisinin olduğunu ortaya koymaktadır.

Moi ve diğerleri (2011) çalışmalarında genç girişimcilerin girişimcilik niyetlerini nelerin etkilediğini araştırmışlardır. Sonuç olarak eğitim, tutum, akademik temel ve aile faktörlerinin etkili olduğunu ortaya koymuşlardır. Çalışmada girişimcilikte eğitimciler, akademisyenler ve politika yapıcılar için girişimcilik niyetinin önemli olduğunu vurgulamışlardır. Taatila ve Down (2012) girişimcilik eğitiminde motivasyonun önemli olduğunu ve öğrencilerin girişimcilik becerilerinin geliştirilmesinde problem çözme ve yeniliğin önemli olduğunu ifade etmişlerdir. Franco ve diğerleri (2010) ise öğrencilerin girişimcilik niyetlerini araştırmışlar ve birçok öğrencinin girişimcilik niyetinin olduğunu ortaya koymuşlardır. Ayrıca çalısmalarında öğrencilerin girişimcilik niyetlerine göre bölgesel farkl1lıklar olduğunu tespit etmişlerdir. Araştırma genel olarak değerlendirildiğinde genç girişimci adaylarının girişimcilik niyetlerinin olduğu görülmektedir. Bu durum araştırma literatürünü desteklemektedir. Burada bireylerin girişimciliğe yönelik tutumları, aldıkları eğitimler, aile desteği, problem çözme ve yenilik becerilerine sahip olabilmeleri gibi olgular etkili olmuş olabilir. Ayrıca uygulama kapsamı Türkiye'de Gümüşhane ve Bayburt'ta yaşayan bireyleri kapsamaktadır. Yani farklı bölgelerde farklı sonuçlar elde edilebilir.

Milheim (2012) bireylerin hayatta kalabilmeleri için çeşitli gıdalara, su ve hava gibi temel ihtiyaçlara gereksinim duyduklarını ifade etmişlerdir. Çalışmada bireylerin girişimcilik niyetleri fizyolojik ihtiyaçlanını olumlu yönde etkilediği görülmektedir. Zira girişimcilik ile elde edilebilecek gelir bireylerin temel ihtiyaçlarını karşılamalarını daha da kolaylaştırabilecektir. Podeschı ve Podeschı (1973) çevresine karşı egemen olan bireylerin güven duygusunu yaşadıklarını ifade etmişlerdir. Zalenski ve Raspa (2006) güvenlik ihtiyacının karşılanmamasının korku, endişe ve kaygıya sebep olabileceğini ifade etmişlerdir. Uygulama bireylerin girişimcilik niyetleri güvenlik duygularını olumlu yönde etkilemiştir. Bu sonuç genç bireylerin korku, endişe ve kaygı durumlarının girişimcilik niyetlerinden elde edebilecekleri ile ortadan kalkabileceği yorumunu yaptırabilmektedir. Taormina ve Gao (2013) uygulamalarında aileden verilen duygusal desteğin ait olma ihtiyacını desteklediğini ifade etmişlerdir. Deibert ve Walsh (1981) ise öğrencilerin ihtiyaçlarının 
tatmin edildiğinde grup içerisinde kendilerini güvende hissettikleri ve dolayısı ile çoğunlukla ait olma duygusuna sahip olduklarını ifade etmişlerdir. Araştırmada bireylerin girişimcilik niyetlerinde en fazla ait olma duygusu etkilendiği gözlemlenmiştir. Bu sonuç bireylerin ailelerinden destek gördüklerini veya girişimcilik niyetleri ile elde edebilecekleri sonucunda aileleri ile daha güçlü ilişkiler gerçekleştirebilecekleri yorumunu yaptırabilir. Zira kültürel (örf, adet, gelenek) olarak Gümüşhane ve Bayburt illerinde ailesel bağlar oldukça güçlüdür. Brenner ve diğerleri (1971), Urwiler ve Frolick (2008) sayg1 ihtiyacını prestij (statü) sahibi olmak ile eşleştirmişlerdir. Milheim (2012) ise bu aşamada bireylerin değerli hissettiklerini ve performanslarına yönelik güven duygularının olması gerektiğini vurgulamıştır. Araşıırmada genç bireylerin girişimcilik niyetleri saygı ihtiyaçlarını olumlu yönde etkilemiştir. Bu sonuç girişimcilik niyetinin bireylerde prestij duygusu uyandırabileceğini ortaya koymaktadır. Saunders ve diğerleri (1998) ise uygulamalarında psikolojik iyilik haline tek katkı sağlamayan değişkenin kendini gerçekleştirme olduğunu vurgulamışlardır. Podeschi (1983) bireylerin kendini gerçekleştirme aşamasına geçmeden önce fizyolojik, güvenlik, ait olma ve saygı ihtiyaçlarının karşılanması gerektiğini ifade etmiştir. Koltko-Rivera (2006) Maslow'un uygulamasında kendini gerçekleştirme ihtiyacını sınırlandırmadığını ifade etmiştir. Araştırmada girişimcilik niyetinin bireylerin kendini gerçekleştirme ihtiyaçlarına önemli derecede ve olumlu bir etkisinin olduğunu ortaya koymaktadır. Bu durum girişimcilik niyeti ile bireylerin kendini gerçekleştirme ihtiyaçları arasında önemli bir ilişkinin olduğunu ortaya koyaktadır. Bu açıdan College (1983) öğrenciler üzerinde gerçekleştirdiği çalş̧masında iç kontrolde güçlü bir inanca sahip olan bireylerin fizyolojik, güvenlik, ait olma, saygı ve kendini gerçekleştirme ihtiyaçlarından memnuniyet duyduklarını ortaya koymuşlardır. Sonuç olarak genç girişimci adaylarının kontrol mekanizmaları dikkate alındığında Maslow'un ihtiyaçlar hiyerarşisinin bütün aşamalarının tam anlamı ile yerine getirilebilmesi için girişimcilik niyetlerini uygulamaya geçirmeleri gerekmektedir. Çünkü girişimcilik niyetleri ihtiyaçlar hiyerarşisinin bütün aşamalarını pozitif ve anlamlı olarak etkilemektedir. Elde edilen bu sonuçlar literatürde ortaya koyulan benzer çalışmaları destekler niteliktedir.

\section{Araştırmanın Literatüre Katkıları}

Araştırmanın teorik katkıları aşağıda maddeler halinde sıralanmıştır;

- Yaşam tarzı, girişimcilik niyeti ve ihtiyaçlar hiyerarşisi araştırmalarına katkıda bulunmaktadır.

- Genç bireylerin girişimcilik niyetlerinde; bireylerin kişisel özelliklerinin yanında, yaşadıkları toplumun eğitim kalitesi, sosyo-ekonomik yapısı ve kültürel özellikleri etkili olduğuna katkıda bulunmaktadır.

- Bireylerin ihtiyaçlar hiyerarşisi; yaşadıkları mikro ve makro çevrenin koşulları ile şekillendiğine katkıda bulunmaktadır.

- Bireyin yaşam tarzı ile (kendine özgü olan, çeşitlilik arayan ve fikir liderliği yapan) bireyler arasında farklılıklar gösterebileceğine katkıda bulunmaktadır.

Araşıtırmanın pratik katkıları aşağıdaki gibi ifade edilebilir;

- Araştırma genç girişimci adayı bireylerin yaşam tarzları, girişimcilik niyetleri ve Maslow'un ihtiyaçlar hiyerarşisi ile birlikte çalışılmış olan illk çalışma (araştırlan çalışmalar içerisinde) olması açısından oldukça önemlidir.

- Genç bireylerin kendine özgü olmaları ve fikir liderliği yapmalarının girişimcilik niyetleri üzerinde pozitif etkilerinin olduğu, çeşitlilik arama ile girişimcilik niyeti arasında ise anlamlı bir ilişkinin olmadığının ortaya koyulması literatüre yeni ve farklı bakış açıları kazandırabilecektir.

- Bireylerin girişimcilik niyetlerinin fizyolojik ihtiyaçları, güvenlik ihtiyaçları, ait olma ihtiyaçları, sayg1 ihtiyaçları ve kendini gerçekleştirme ihtiyaçları üzerinde pozitif etkisinin olduğu anlaşılmaktadır. Bu sonuçlar ile literatüre farklı bir bakış açısı kazandırılabilir. Zira teorik olarak genellikle ihtiyaçlar hiyerarşisinin girişimcilik niyeti üzerindeki etkilerinin araştırlması uygun görülse de çalışmada girişimcilik niyetinin ihtiyaçlar hiyerarşisi üzerindeki etkileri araştırılmışır. Sonuç olarak en fazla ait olma ihtiyac1, kendini gerçekleştirme, sayg1, güvenlik ve fizyolojik ihtiyaçların etkilendiği araştırma sonuçlarında ortaya koyulmuştur.

- Genç girişimci adayı bireylerin girişimcilik niyetleri Maslow’un ihtiyaçlar hiyerarşisinin bütün aşamalarını pozitif yönde etkilemiştir. Bu sonuç bireylerin hiyerarşiyi tam anlamıyla gerçekleştirmek istemelerinde girişimcilik niyetlerinin büyük öneminin olduğunu ortaya koymaktadır.

- Uygulama sonuçları ile bireylerin girişimcilik niyetleri için pratik tavsiyeler sunulmaktadır. 
$\mathrm{Bu}$ sonuçlar ile genç girişimci adayı bireylerin yaşam tarzlarına, girişimcilik niyetlerine ve ihtiyaçlar hiyerarşisine farklı bakış açıları kazandırılmıştır.

Gelecek nesillere; bölgelerin, ülkelerin kısacası büyük ölçekte toplumların kalkınmasında büyük işler düşmektedir. $O$ halde genç nesillerin yaşam tarzları, girişimcilik niyetleri ve ihtiyaçlarının nasıl şekillendiğinin belirlenmesi gerekmektedir. Bu açıdan gelecek araştırmalarda genç bireylerin temel ihtiyaçlarının neler olduğu bu ihtiyaçların karşılanması ile ülke ekonomisine ne gibi katkılar yapmayı düşündükleri ve bu düşüncelerini ne tür değişkenler kullanarak gerçekleştirebileceklerini ortaya koymak önemli olacaktır. Çalışma sadece genç bireyler incelenmiştir. Uygulama daha yetişkin (birçok tecrübesi olan) kişiler üzerinde uygulanabilir. Sonuç olarak daha önce gerçekleştirilen çalışmalar incelendiğinde bireylerin yaşam tarzlarının girişimcilik niyetleri, girişimcilik niyetlerinin de ihtiyaçlar hiyerarşisi üzerindeki etkilerini ortaya koyabilecek bir çalışmaya rastlanılmamış olması çalışmayı bu alanda değerli kılmaktadır.

\section{Etik Beyan}

"Maslow'un İbtiyaçlar Hiyerarşisinin Genç Bireylerin Yaşam Tarzllar İle Girişimcilik Niyetleri Açısından Incelenmesi”" başlıklı çalışmanın yazım sürecinde bilimsel, etik ve alıntı kurallarına uyulmuş; toplanan veriler üzerinde herhangi bir tahrifat yapılmamış ve bu çalışma herhangi başka bir akademik yayın ortamına değerlendirme için gönderilmemiştir.

\section{Kaynakça}

Adler, S. (1977). Maslow's need hierarchy and the adjustment of 1mmigrants. The International Migration Review, 11(4), 444-451.

Atef, T. M. ve Al-Balushi, M. (2015). Entrepreneurship as a means for restructuring employment patterns. Tourism and Hospitality Research, 15(2), 73-90.

Audretsch, D. B., Kuratko, D. F. ve Link, A. N. (2015). Making sense of the elusive paradigm of entrepreneurship. Small Business Economics, 45(4), 703-712.

Autı, E., Keeley, R. H., Klofsten, M., Parker, G. G. C. ve Hay, M. (2001). Entrepreneurial intent among students in scandinavia and in the USA. Enterprise and Innovation Management Studies, 2(2), 145-160.

Baer, M. D., Rodell, J. B., Dhensa-Kahlon, R. K., Colquitt, J. A., Zipay, K. P., Burgess, R. ve Outlaw, R. (2018). Pacification or aggravation? The effects of talking about supervisor unfairness. Academy of Management Journal, 61(5), 1764-1788.

Baş, T. (2008). Anket nasıl hazırlanır? Anket nasıl uygulanır? Anket nasıl değerlendirilir? İstanbul: Seçkin Yayıncilık.

Battal, F. ve Durmuş, İ. (2017). Modern ahilik ölçeği geçerlik ve güvenirlik çalışması. Akademik Bakış Dergisi, 63, 7184.

Bavelas, A. (1960). Leadership: Man and function. Administrative Science Quarterly, 4(4), 491-498.

Benson, S. G. ve Dundis, S. P. (2003). Understanding and motivating health care employees: Integrating Maslow's hierarchy of needs, training and technology. Journal of Nursing Management, 11, 315-320.

Berl, R. L, Williamson, N. C. ve Powell, T. (1984). Industrial salesforce motivation: A critique and test of Maslow's hierarchy of need. The Journal of Personal Selling and Sales Management, 4(1), 32-39.

Brenner, V. C., Carmack, C. W. ve Weinstein, M. G. (1971). An empirical test of the motivation-hygiene theory. Journal of Accounting Research, 9(2), 359-366.

Brown, T. E., Davıdsson, P. ve Wiklund, J. (2001). An operationalization of Stevenson's conceptualization of entrepreneurship as opportunity-based firm behavior, Strategic Management Journal, 22(10), 953-968.

Bouzenita, A. I. ve Boulanouar, A. W. (2016). Maslow's hierarchy of needs: An Islamic critique. Intellectual Discourse, 24(1), 59-81.

Cao, H., Jiang, J., Oh, L., Li, H., Liao, X. ve Chen, Z. (2012). A Maslow's hierarchy of needs analysis of social networking services continuance. Journal of Service Management, 24(2), 170-190.

Chang, S. (2008). Work role stressors and turnover intentions: A study of IT personnel in South Korea. German Journal of Research in Human Resource Management, 22(3), 272-290.

Chung, K. H. (1969). A Markov chain model of human needs: An extension of Maslow's need theory. The Academy of Management Journal, 12(2), 223-234.

Claire, L. (2012). Re-storying the entrepreneurial 1deal: Lifestyle entrepreneurs as hero? Tamara-Journal for Critical Organization Inquiry, 10(1), 31-39.

Cloke, P., Milbourne, P. ve Thomas, C. (1997). Living lives in different ways? Deprivation, marginalization and changing lifestyles in rural England. Transactions of the Institute of British Geographers, 22(2), 210-230.

College, R. S. S. (1983). Maslow's hierarchy of needs and psychological health. The Journal of General Psychology, 109, 83-85.

Coviello, N. (2015). Re-thinking research on born globals. Journal of International Business Studies, 46(1), 17-26.

Crant, J. M. (1996). The proactive personality scale asa predictor of entrepreneurial intentions. Journal of Small Business Management, 34(3), 42-49.

Cronbach, L. J. (1951). Coefficient alpha and the internal structure of tests. Psychometrika, 16(3), 297-334. 
Dalvi, M. R., Haery, F. A. ve Ebrahimi, H. (2013). Investigating the effects of reward on the cooperation in the sale and marketing department from managers perspective (Isfahan food industries case study). International Journal of Academic Research in Business and Social Sciences, 3(11), 144-153.

Deibert, J. P. ve Walsh, K. J. (1981). Maslow and team organization. The Clearing House, 55(4), 169-170.

Dennis, L. J. ve Powers, J. F. (1974). Dewey, Maslow, and consummatory experience. The Journal of Aesthetic Education, 8(4), 51-63.

Dohse, D. ve Walter, S. G. (2012). Knowledge context and entrepreneurial intentions among students, Small Business Economics, 39(4), 877-895.

Dye, K., Mills, A.J. ve Weatherbee, T. (2005). Maslow: Man interrupted: reading management theory in context. Management Decision, 43(10), 1375-1395.

Franco, M., Haase, H. ve Lautenschlager, A. (2010). Students' entepreneurial intentions: An inter-regional comparison. Education + Training, 52(4), 260-275.

Gartner, W. B. (2008). Variations in entrepreneurship. Small Business Economics, 31(4), 351-361.

Gawel, J. E. (1997). Herzberg's theory of motivation and Maslow's hierarchy of needs. Practical Assessment, Research \& Evaluation, 5(11), 1-3.

Gemmill, G. ve Oakley, J. (1992). Leadership: An alienating social myth? Human Relations, 45(2), 113-129.

Gilgun, Jane F. (1992). Hypothesis generation in social work research. Journal of Social Service Research, 15(3/4), 113135.

Graham, W. K. ve Balloun, J. (1973). An empirical test of Maslow's need hierarchy theory. Journal Humanistic Psychology, 13(1), 97-108.

Gratton, L. C. (1980). Analysis of Maslow's need hierarchy with three social class groups. Social Indicators Research, $7(1 / 4), 463-476$.

Harris, A. ve Spillane, J. (2008). Distributed leadership through the looking glass. Management in Education, 22(1), 31 34.

Huang, Y. H., Ho, M., Smith, G.S. ve Chen, P. Y. (2006). Safety climate and self-reported injury: Assessing the mediating role of employee safety control. Accident Analysis and Prevention, 38, 425-433.

Kım, Y. (2010). Improving performance in U.S. state goverments: RİSK-Taking, innovativeness, and proactiveness practices. Public Performance \& Management Review, 34(1), 104-129.

Koltko-Rivera, M. E. (2006). Rediscovering the later version of Maslow's hierarcy of needs: Self-transcendence and opportunities for theory, Research, and Unification. Review of General Psychology, 10(4), 302-317.

Kuratko, D. F., Morris, M. H. ve Schindehutte, M. (2015). Understanding the dynamics of entrepreneurship through framework approaches. Small Business Economics, 45(1), 1-13.

Kyrö, P. ve Fayolle, A. (2008). Introduction: Broadening the scope and dynamics of entrepreneurship research in Europe. European Research in Entrepreneurship, 1-12.

Laceulle, H. (2018). Chapter title: Self-realization (Aging and Self-Realization). Cultural Narratives About Later Life, 93126.

Lazear, E. P. (2005). Entrepreneurship. Journal of Labor Economics, 23(4), 649-680.

Lester, D. (2013). Measuring Maslow's hierarchy of needs. Psychological Reports: Mental \& Physical Health, 113(1), 15-17.

Loftus, G. R. (1991). On the tyranny of hypothesis testing in the social sciences. Contemporary Psychology, 36(2), 1-6.

Maslow, A. H. (1943). A theory of human motivation, Psychological Review, 50(4), 370-396.

Maslow, A. H. ve Honigmann, J. J. (1970). Synergy: Notes of ruth benedict. American Antropologist, New Series, 72(2), 320-333.

Massey, R. J. (1954). The entrepreneur: Who is he? Relations Industrielles / Industrial Relations, 9(3), 245-251.

Mathes, E. W. (1981). Maslow's hierarchy of needs as a guide for living. Journal Humanistic Psychology, 21(4), 69-72.

Milheim, K. L. (2012). Toward a better experience: examining student needs in the online classroom through Maslow's hierarchy of needs model. MERLOT Journal of Online Learning and Teaching, 8(2), 159-171.

Moi, T., Adeline, Y. L. ve Dyana, M. L. (2011). Young adult responses to entrepreneurial intent. International Refereed Research Journal, 2(3), 37-52.

Montanye, J. A. (2006). Entrepreneurship. The Independent Review, 10(4), 547-569.

Moosmayer, D. C. (2012). A model of management academics intentions to influence values. Academy of Management Learning \& Education, 11(2), 155-173.

Murray, H. A., Skinner, B. F., Maslow, A. H., Rogers, C. R., Frank, L. K., Rapoport, A. ve Hoffman, H. (1961). Cultural Evolotuin as Viewed by Psychologists. Daedalus, 90(3), 570-586.

Olson, L. N. (2002). 'As ugly and painful as it was, it was effective:' individuals unique assessment of communication competence during aggressive conflict episodes. Communication Studies, 53(2), 171-188.

Olufunso, F. O. (2010). Graduate entrepreneurial intention in South Africa: Motivations and obstacles. International Journal of Business and Management, 5(9), 87-98.

Peters, M., Frehse, J. ve Buhalis, D. (2008). The 1mportance of lifestyle entrepreneurship: A conceptual study of the tourism industry. Revista de Turismo y Patrimonio Cultural, 7(2), 393-405.

Pines, A. M., Lerner, M. ve Schwartz, D. (2010). Gender differences in entrepreneurship: Equality, diversity and inclusion in times of global crisis. Equality, Diversity and Inclusion An International Journal, 29(2), 186-198.

Podeschi, R. L. (1983). Maslow's dance with philosophy. Journal of Thought, 18(4), 94-100. 
Podesch1, R. L. ve Podeschi, P. J. (1973-74). Abraham Maslow: On the potential of women. Educational Horizons, 52(2), 61-64.

Qian, H. (2013). Diversity versus tolerance: The social drivers of innovation and entrepreneurship in US cities. Urban Studies, 50(13), 2718-2735.

Qiu, S., Wang, P. ve Yang, P. (2015). The impact of personal psychology and behavior factors on the innovation assimilation of secure system development, American Journal of Industrial and Business Management, 5, 181-191.

Reiss, S. (2004). Multifaceted nature of intrinsic motivation: The theory of 16 basic desire. Review of General Psychology, $8(3), 179-193$.

Saeednia, Y. (2011). Generating a scale measuring hierarchy of basic needs. Procedia Social and Behavioral Sciences, 15, 3084-3094.

Sahut, J. M. ve Peris-Ortiz, M. (2014). Small business, innovation, and entrepreneurship. Small Business Economics, 42(4), 663-668.

Salancik, G. R. ve Pfeffer, J. (1977). An examination of need-satisfaction models of job attitudes. Administrative Science Quarterly, 22(3), 427-456.

Saunders, S., Munro, D. ve Bore, M. (1998). Maslow's hierarchy of needs and its relationship with psychological health and materialism. South Pacific Journal of Psychology, 10(2), 15-25.

Sengupta, S. S. (2011). Growth in human motivation: Beyond Maslow. Indian Journal of Industrial Relations, 47(1), $102-$ 116.

Sevari, K. (2017). Construction and validation of main psychological needs scale. American Journal of Applied Psychology, 5(1), 7-11.

Shinnar, R., Pruett, M. ve Toney, M. (2009). Entrepreneurship education: Attitudes across campus. Journal of Education for Business, 84(3), 151-159.

Smith, G. R., Gregory, T. B. ve Pugh, R. C. (1981). Meeting student needs: Evidence for the superiority of alternative schools. The Phi Delta Kappan, 62(8), 561-564.

Smith, M. B. (1991). Comment on Davies's “Maslow and theory of political development". Political Psychology, 12(3), 421-423.

Stam, E. (2008). Entrereneurship and innovation. Micro-foundtions for innovation policy (Ed., B. Nooteboom, E. Stam), Amsterdam University Press, 135-172.

Taatila, V. ve Down, S. (2012). Measuring entepreneurial orientation of university students. Education + Training, 54(8/9), 744-760.

Taormina, R. J. ve Gao, J. H. (2013). Maslow and the motivation hierarchy: Measuring satisfaction of the needs. The American Journal of Psychology, 126(2), 155-177.

Tomlinson, M. (2003). Lifestyle and social class. European Sociological Review, 19(1), 97-111.

Urwiler, R. ve Frolick, M. N. (2008). The IT value hierarchy: Using Maslow's hierarchy of needs as a metaphor for gauging the maturity level of information technology use within competitive organizations. Information Systems Management, 25(1), 83-88.

Valentine, S., Godkin, L., Fleischman, G. M., Kidwell, R. E. ve Page, K. (2011). Corporate ethical values and altruism: The mediating role of career satisfaction. Journal of Business Ethics, 101(4), 509-523.

Valentine, S. R. ve Rittenburg, T.L. (2004). Spanish and American business professionals ethical evaluations in global situations. Journal of Business Ethics, 51(1), 1-14.

Valikhani, M., Hashempoor, E., Vastegani, B. M. (2015). Investigating the effect of job-related motivational factors on the employee and organizational performance through mediating role of organizational participation (Entekhab industrial group case study). International Journal of Academic Research in Business and Social Sciences, 5(7), $1-13$.

Ventegodt, S., Merrick, J. ve Andersen, N. J. (2003). Quality of life theory III. Maslow revisited. The Scientific World Journal, 3, 1050-1057.

Weinberg, H. (2005). The effective time-binder and Maslow's “self-actualizing person”. A Review of General Semantics, 62(3), 313-317.

Welter, F., Baker, T., Audretsch, D. B. ve Gartner, W. B. (2016). Everyday entrereneurship a call for entrepreneurship research to embrace entrepreneurial diversity. Entrepreneurship Theory and Practice, 1-11.

White, R. E. ve Pierce, B. D. (2000). On Maslow, monkeys, and evolution. The Academy of Management Review, 25(4), 697-699.

Yang, K. C. C. (2004). A comparison of attitudes towards internet advertising among lifestyle segments in Taiwan. Journal of Marketing Communications, 10(3), 195-212.

Zakaria, M. ve Malek, N. A. A. (2014). Effects of human needs based on the integration of needs as stipulated in Maqasid Syariah and Maslow's hierarchy of needs on zakah distribution efficiency of asnaf assistance business program. Jurnal Pengurusan, 40, 41-52.

Zalenski, R. J. ve Raspa, R. (2006). Maslow's hierarchy of needs: A framework for achieving human potential in hospice. Journal of Palliative Medicine, 9(5), 1120-1127.

Zgheib, P. W. ve Kowatly, A. K. (2011). Autonomy, locus of control, and entepreneurial orientation of lebanese expatriates worldwide. Journal of Small Business and Entrepreneurship, 24(3), 345-360. 


\section{EXTENDED ABSTRACT}

Entrepreneurship intentions of young individuals in their expectations about the future are very important. Because the risk of private sector interventional activities directly affect these individuals themselves. In this respect, various alternatives are determined by the entrepreneur candidates about entrepreneurship intentions. In today's world of innovation, these alternatives can change the lifestyles of young people in particular. The entrepreneurial intentions of these young people can be influenced by the social and cultural structure of the society, economic and political structures. These factors that can affect the lifestyle variables and entrepreneurial intentions of individuals in different environments can shape their hierarchy of needs. In this research; In the study model, Yang (2004) 's lifestyle variables (self specificity, diversity seeking and idea leadership) scales that were discussed in the study, the scale of entrepreneurial intention of Olufunso (2010) and Maslow's formed by Taormina and Gao (2013)'s unrequirements hierarchy scales (physiological needs, need for security, need for belonging, need for respect and self-fulfillment) were used. While creating the study model and hypotheses, other previous studies were taken into consideration and expressed in the theoretical framework and in the results section.

Practice living in the Black Sea Region of Turkey in the year 2019343 young entrepreneurs to (or who have completed continuing education that up to 5 years) was applied to the electronic survey. Most of the young people who participated in the study were women (177 persons - \% 51.6). In practice, it was observed that most individuals had a monthly income of 2000 TL or less (209 persons - \% 60.9). Also, it was observed that most of the young individuals (128 people - \% 37.3) were middle school or high school graduates and 23 or 24 years old (79 people - \% 23.0). SPSS and AMOS package programs were used in the study. Structural Equation Model (SEM) was applied with the help of these programs. The data revealed that the research model variables were valid and reliable. In other words, Cronbach Alpha $=, 946$ and its validity $\mathrm{KMO}=, 890$ were used to determine the reliability of the study. In the study, it was observed that the total contribution of the 9 factors to the explained variance was $\% 68,234$. The results obtained indicate that the study scale has valid and reliable results. In this study, hypothesis h2 was rejected and, hypotheses h1, h3, h4, h5, h6, h7, and h8 were accepted. In terms of the hypotheses of the hypothesis $\mathrm{H1}$; the fact that young individuals were unique had a positive impact on entrepreneurial intentions. H2 hypothesis; It was concluded that individuals' diversity searches had no significant effect on entrepreneurship intentions. H3 hypothesis; The fact that the individuals who are young entrepreneur candidates are opinion leaders has positively influenced their entrepreneurial intentions. The H4 hypothesis, individuals entrepreneurial intentions positively influenced their physiological needs. H5 hypothesis; the entrepreneurship intentions of young individual have positively affected security needs. H6 hypothesis; individual's entrepreneurial intentions have positively affected their need to belong. $\mathrm{H} 7$ hypothesis; The intention of entrepreneurship influenced positively the needs of respect and in hypothesis h8; the intention of entrepreneurship has also positively affected the needs of individuals to realize themselves.

When the results of the application were examined in general, significant relationships were obtained in the variables other than the diversity search variable of the individuals. When these relationships and their effects are examined, individuality and idea leadership affect entrepreneurial intentions both to a high degree and in a positive way. Entrepreneurship intentions of young individuals positively affect their needs for self-realization, respect needs, security needs, and physiological needs according to their level of influence. These results show that individuals have more influence on the end stages of the hierarchy of needs hierarchy in general. In other words, these results indicate that individuals are more likely to achieve satisfaction at the highest levels of entrepreneurial intention and that this may trigger more entrepreneurial intentions of entrepreneurial candidates. In practice, the effects of entrepreneurial intentions on individuals' lifestyle variables were measured. Besides, the effects on the hierarchy of needs in the entrepreneurial intentions of young individuals were also measured. The results are very interesting. Because the young individuals acted unique and had a positive impact on their entrepreneurship intentions, diversity searches did not affect. In another aspect, individuals' entrepreneurial intentions have had a positive impact on Maslow's entire hierarchy of needs. This result reveals that the hierarchical structure creates linear effects with the intention of entrepreneurship. It is thought that the study will give different perspectives to the literature. 